\title{
It's Getting Better All the Time: Comparative Perspectives from Oceania and West Africa on Genetic Analysis and Archaeology
}

\author{
Susan Keech McIntosh • Laura B. Scheinfeldt
}

(C) Springer Science+Business Media, LLC 2012

\begin{abstract}
Technological advances are making genetic data collection and analysis feasible on a scale unimaginable only a few years ago. Early genetic research using mitochondrial DNA and the Y chromosome provided important insights for macroscale modeling of regional and continent-wide population movements, but the capacity to study the entire genome now opens an era of finer-grained, mesoscale studies of regional and local population histories that are more compatible with the scale of archaeological analysis. The utility of integrating both types of data is illustrated by a case study from Oceania, where genetic studies were used to evaluate two models for the geographic origins of the populations that colonized Polynesia beginning ca. $3000 \mathrm{BP}$, bringing with them the distinctive Lapita cultural assemblage. A second case study considers the application of genetic studies to an understanding of Fulbe history, especially that of the pastoral Fulbe. Both archaeological and genetic data are underdeveloped for the key Fulbe homeland regions of Mauritania and Senegal, but recent research in the Middle Senegal Valley permits some conjectures on the history of Fulbe nomadic pastoralism. The article concludes with suggestions for a multidisciplinary research agenda to expand and upgrade the quality of relevant archaeological data, incorporate biodistance studies of human skeletal material, and improve and expand genetic sampling using more historically sensitive collection protocols.
\end{abstract}

Résumé Les avancées technologiques permettent la collecte et l'analyse de données génétiques à une échelle inimaginable ne serait-ce qu'il y a quelques années. Les premières recherches génétiques utilisant l'ADN mitochondrial et le chromosome Y ont

\footnotetext{
S. K. McIntosh $(\bowtie)$

Department of Anthropology, Rice University, P.O. Box 1892, Houston, TX 77251, USA

e-mail: skmci@rice.edu

L. B. Scheinfeldt

Department of Genetics, School of Medicine, University of Pennsylvania, 430 Clinical Research

Building 415 Curie Boulevard, Philadelphia, PA 19104-6145, USA

e-mail: 1scheinf@mail.med.upenn.edu
} 
fourni des renseignements importants pour la modélisation à la macro-échelle des mouvements de population régionaux et continentaux. Mais la capacité d'étudier l'ensemble du génome ouvre maintenant une ère d'études plus précises à la méso-échelle —études de l'histoire des populations locales et régionales plus adaptées à l'échelle de l'analyse archéologique. L'utilité de l'intégration des deux types de données est illustrée par une étude de cas située en Océanie, où les études génétiques ont été utilisées pour évaluer les deux modèles sur l'origine des populations qui ont colonisé la Polynésie, dès 3000 ans BP et apporté avec eux l'ensemble culturel distinctif appelé Lapita. Une deuxième analyse examine l'application des études génétiques à une meilleure compréhension de l'histoire des Peuls (Fulbé), en particulier celle des Fulbé pastoralistes. Les données archéologiques et génétiques sont sous-développées pour les foyers de population Fulbe en Mauritanie et au Sénégal, mais des recherches récentes dans la vallée du Moyen-Sénégal permettent quelques hypothèses sur l'histoire du pastoralisme nomade Fulbe. L'article conclut avec des suggestions pour un programme de recherches multidisciplinaires destiné à élargir et améliorer la qualité des données archéologiques pertinentes, d'intégrer des études d'affinité biologique de matériel squelettique humain, et d'améliorer et d'élargir l'échantillonnage génétique en utilisant des protocoles de collection plus sensibles à la dimension historique.

Keywords Fulbe history $\cdot$ Genetic $\cdot$ Migration $\cdot$ Pastoralists

\section{Introduction}

Over the past two decades, genetic analysis has become an important tool for exploring past population movements. Mitochondrial DNA (mtDNA) and the nonrecombinant portion of the $\mathrm{Y}$ chromosome (NRY) have been used to infer the origin and directional spread of genetic variants present in modern DNA, permitting the modeling of, for example, the movement of modern humans out of Africa, the peopling of the Americas, the spread of early farmers in Europe, and the Bantu expansion (Scheinfeldt et al. 2010; Soares et al. 2010; Tishkoff et al. 2009; Underhill $\&$ Kivisild 2007). Where archaeology has documented the spread of technologies (e.g., food production) and/or cultural traits, genetic studies can, in some cases, help differentiate between past migration of peoples (demic diffusion) and movement of artifact technologies and languages without genes (cultural diffusion). Recently, new technologies have made it possible to go beyond mtDNA and NRY studies and analyze hundreds of thousands of genetic variants from across the entire genome to explore these questions. Combined with the increased geographical and temporal resolution made possible by rapid, automatic sequencing of the mtDNA and NRY genomes, this heralds a new phase in analysis that may result in a greater alignment in scale of genetic and archaeological data. In particular, more precise dating of the appearance and spread of genetic variants will encourage more detailed arguments linking genetic patterns with well-dated archaeological phenomena. Genetic analysis may transcend its current emphasis on macroscale processes at a continental or even global level and target mesoscale processes of regional and local differentiation that are more compatible with the scale of archaeological analysis. In this article, we explore how archaeological, genetic, and, to a lesser extent, linguistic evidence can be 
deployed in an integrated research program to address specific historical questions regarding population movements and interactions involving gene flow.

We present two illustrative case studies. The first is from Oceania, where an expansive migration of Austronesian language speakers in the late fourth millennium BP pushed into previously uninhabited islands in Polynesia, accompanied by the distinctive Lapita cultural assemblage, which also appears in Melanesia. Genetic analysis attempts to identify the source area(s) of this population expansion. Did newcomers from the Austronesian language source area in Southeast Asia expand into Melanesia and Polynesia beginning 3,300 years ago, introducing the Lapita assemblage along the path of their migration, or was it a more complex process involving local development of Lapita by Melanesians who then carried it to Polynesia? This case study utilizes fairly extensive genetic sampling of diversity in New Guinea and the Bismarck Archipelago, the region in Melanesia with the earliest Lapita sites. As we shall see, even when relevant archaeological and genetic data are relatively abundant, interpretation is difficult, but in this case, it was possible to refute two of the proposed migration models.

The second case study considers whether genetic analysis can shed light on particularities of the history of the Fulbe (Fulani, Fellata, Peul), a pastoral group that is widely distributed across the Sudanic region of Africa. Linguistically, they belong to the family of Atlantic languages, yet arguments have been advanced (supported by the Fulbe's own oral histories) for origins in the Near East, Egypt, or elsewhere in northeast Africa. As we know them ethnohistorically, the pastoral Fulbe have a number of distinctive characteristics: a high frequency of physical traits suggestive of Mediterranean (North African, Near Eastern) and sub-Saharan admixture (Hiernaux 1975); Fulfulde language, a distinctive, cattle-based pastoral system and ideology, high levels of mobility, and low levels of archaeological visibility. When and where did the component elements of this Fulbe package of traits emerge? Can a genetic signature of an early demic expansion from the northeast be detected? Or would any such signature be overwritten by the complexities of the Fulbe's recent historical diaspora from west to east? Can genetic analysis reveal anything about the relative antiquity of the introduction of DNA from northern populations (Europe, North Africa, and the Near East) into populations ancestral to the Fulbe? We review the genetic studies conducted to date and discuss their limitations. Archaeological data are essential to the investigation of past pastoral systems and cultural patterns with possible links to Fulbe prehistory. However, the current state of archaeology in much of the relevant area of Africa provides very limited information for our inquiries, with the exception of the Middle Senegal Valley homeland of the historic Fulbe. Additional sources of evidence will be needed to tease apart the tangled deeptime history of the Fulbe. Based on current evidence, we propose that certain cultural aspects of the ethnohistoric Fulbe package, namely, specialized, semi-nomadic pastoralism, developed only in the last millennium out of more generalized agropastoral precursors. Evaluating this proposal and the other Fulbe components will require high quality, multidisciplinary data. We conclude with suggestions for a research agenda designed to upgrade the quality of relevant archaeological data, incorporate biodistance studies of human skeletal material, and expand and improve genetic sampling using more sophisticated collection protocols, additional population samples, and additional genetic loci for analysis. 


\section{The Analysis of Genetic Variation}

\section{Uniparentally Inherited Genetic Variation-mtDNA and NRY}

MtDNA and NRY have two characteristics that make them very useful for investigations of human demographic history: like all chromosomes, they have noncoding regions (i.e., regions of DNA that do not code for genes) that can accumulate mutations much faster than coding sectors where mutations may affect function, and they are inherited uniparentally without recombination (the shuffling of chromosomes that occurs between the 22 paternal and maternal autosomal chromosomes each generation). Thus, the pattern of accumulated mutations is passed down intact, exclusively from mother to child in the case of mtDNA and from father to son for NRY, allowing the reconstruction of maternal and paternal population histories. Through time, new variants continue to arise through mutation, with two types of variant particularly relevant for studies of past population movements:

1. Biallelic variants, including single nucleotide polymorphisms (SNPs), which result from a mutation in a nucleotide base (abbreviated as A, C, G, and T) producing a second form, or allele, at a particular position on the chromosome; and in/dels, involving the insertion or deletion of one or more bases at a particular position (Fig. 1).

2. Multiallelic variants, particularly single tandem repeats (STRs, or microsatellites) which are mutations involving repetition of a short sequence of two to six bases at a particular position (Fig. 1); the number of repeats defines each allele.

By studying the patterning of biallelic variants in primarily the noncoding, hypervariable segments (HVS) of the mtDNA, it has been possible to identify almost 7,000 sequence variants, which define particular lineages called haplotypes. These have been partitioned into approximately $90 \mathrm{mtDNA}$ haplogroups, each one defined by a small set of shared biallelic SNP or in/del polymorphisms (Brown \& Brown 2011, p. 177). The haplogroup mutations arose in a cumulative fashion over time, so that a haplogroup sublineage contains all the mutations of its parental lineage. The same principle underlies the recognition of NRY haplogroups. Figures 2 and 3 show genealogies of mtDNA and NRY haplogroups respectively. MtDNA haplogroup B, for example (Ruiz-Pesini et al. 2007; van Oven \& Kayser 2009), contains its own defining mutations (including a 9-bp deletion) as well as the mutations that define haplogroups R, N, and L3. Similarly, NRY haplogroup O contains its own defining mutations (including M175) as well as the mutations that define haplogroups $\mathrm{K}$ and $\mathrm{F}$ (Karafet et al. 2008). These haplogroup variants are assumed to have arisen only once in modern human history [although this is not always the case (e.g., Redd et al. 1995)]; therefore, individuals that share the same haplogroup variants are assumed to share ancestry with the last common ancestral population containing that haplogroup.

reference strand of DNA:

SNP:

insertion:

6 bp deletion:

STR:
AATGCAACCGTGAAGGTCTCACCGTTATATGAGTGCA AATACAACCGTGAAGGTCTCACCGTTATATGAGTGCA AATGAGGCCAACCGTGAAGGTCTCACCGTTATATGAGTGCA AATG-----TGAAGGTCTCACCGTTATATGAGTGCA

AATGTTTATTTATTTATTTATTTATTTATTTACAACCGTGAAGGTCTC

Fig. 1 Illustrative examples of SNP, in/del, and STR variants 


\section{mtDNA Haplogroup Tree}

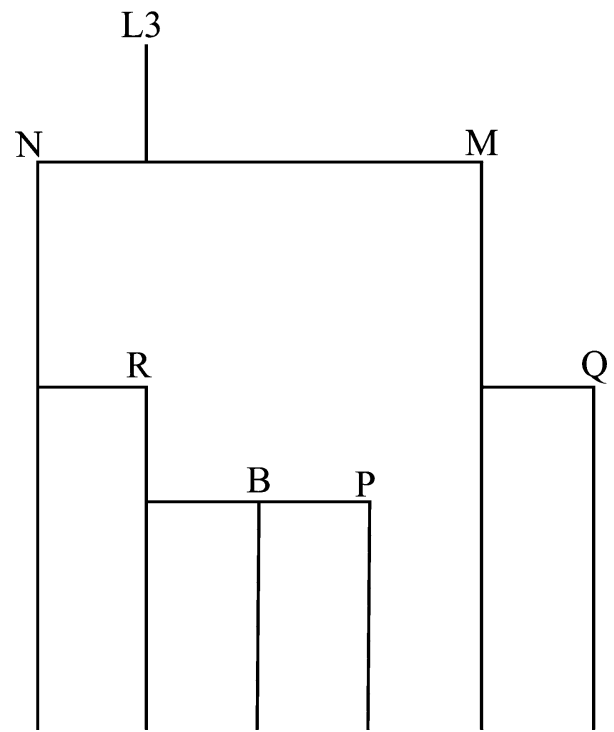

Fig. 2 An mtDNA haplogroup tree. Each branch represents a haplogroup lineage within haplogroup L3

The geographic distribution of the various haplogroups suggests a process of migration from Africa, gradually spreading across the world (Cann et al. 1987; Garrigan et al. 2007; Underhill et al. 2001).

Because uniparentally inherited mtDNA and NRY are not subject to the unpredictable shuffling that occurs during recombination, they can be used to reconstruct

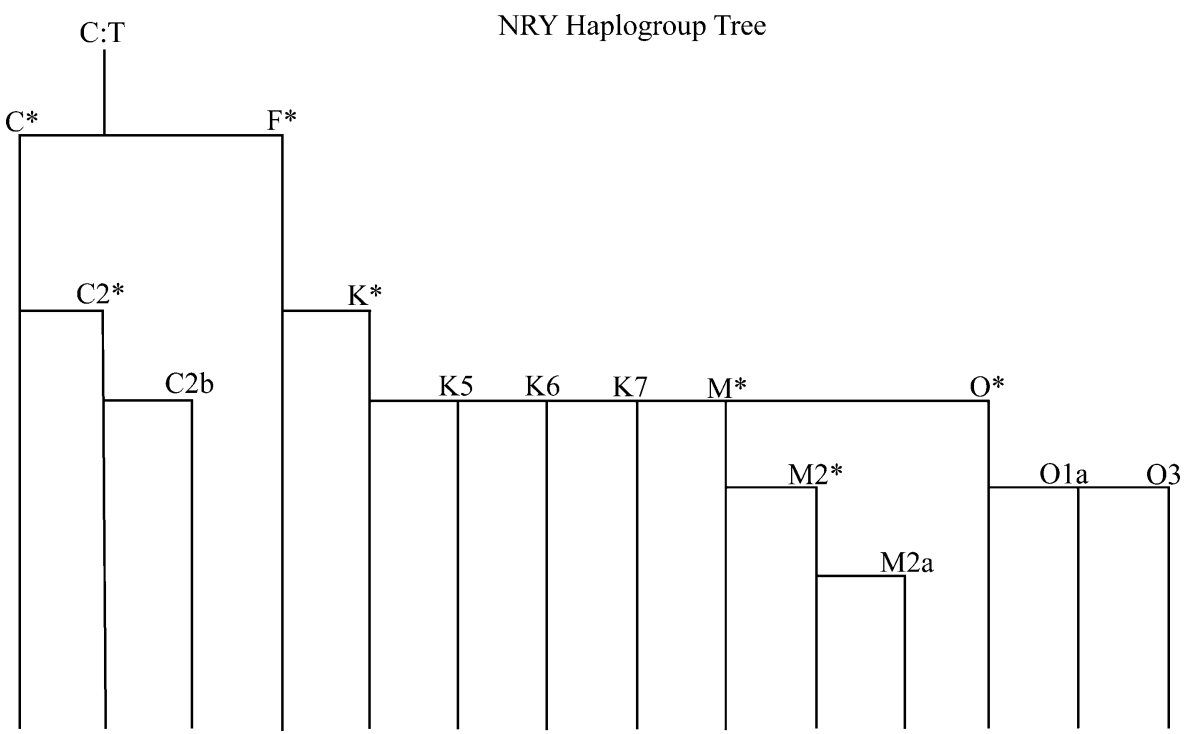

Fig. 3 A Y chromosome haplogroup tree. Each branch represents a haplogroup lineage within haplogroups C:T 
several demographic parameters, including the time to the most recent common ancestral population, effective population size (the number of breeding individuals in the ancestral population), past gene flow, and past migration events. Estimating the time that has elapsed since a haplogroup came into existence (the coalescence time) considers the amount of diversity present within each haplogroup. Since greater diversity is the result of a larger number of mutations, which accumulate as a function of time since the emergence of the founding mutation(s) of the haplogroup, it is possible to assign an approximate date to that event if the mutation rate (generally assumed to be constant) can be estimated. This type of molecular dating requires some important caveats: when hyper-variable variants (from mtDNA or NRY) are used to estimate the absolute age of a haplogroup lineage, any variant within the lineage that has arisen more than once will bias the estimated age, and the absolute ages are dependent on an accurate mutation rate. Many studies include extremely large confidence intervals to compensate for these uncertainties.

When these analyses are used to infer migration patterns, it is generally assumed that the contemporary population with the highest levels of within-haplogroup diversity descends directly from the population in which the haplogroup arose. This assumption is based on two properties of population genetic modeling: The longer a haplogroup lineage has been in existence, the more mutations accumulate within it; and populations that migrate away from the source population generally carry only a subset of the variation present in the source population (sometimes referred to as a bottleneck or founder effect). Thus, analyses of haplogroup diversity in the source and migrant populations can be used to estimate the time that the two populations separated from each other (e.g., Brown \& Brown 2011, p. 225). However, diversity can be affected at any point by the random effects of genetic drift (random fluctuations of allele frequencies in a population each generation), especially in small populations, and this may obscure demographic inference.

For all its advantages, there are limitations to the analysis of mtDNA and NRY. To begin with, they represent a very small proportion of the overall genomic variation $(\sim$ $1.8 \%$ ) of an individual or population. MtDNA or NRY provide information on only one of the 256 lineal ancestors that contributed to the genetic makeup of an individual over a seven generation span. It therefore tells a very partial historical tale. In addition, both loci have a small (0.5) effective population size (one copy of the mtDNA and NRY is present in each individual) relative to the rest of the autosomal chromosomes (two copies are present in each individual) and are therefore more susceptible to the effects of genetic drift. In addition, there is evidence, though somewhat contentious, that these loci have been affected by natural selection (Kivisild et al. 2006), and if/when this is the case, variation at the entire locus will be affected (and often reduced) also obscuring demographic inference, because both the mtDNA and NRY are inherited as single units. Therefore, caution must be used in the interpretation of mtDNA and NRY data.

Anthropological geneticists have often used mtDNA and NRY to study human migration patterns (e.g., Beleza et al. 2005; Karafet et al. 2002; Malhi et al. 2004; Manni et al. 2002). Many studies have characterized the distribution of mtDNA and NRY haplogroups worldwide. For example, mtDNA haplogroup B is common in populations residing in Asia, the Americas, and the Pacific (Friedlaender et al. 2005; 
Merriwether et al. 1999; Ruiz-Pesini et al. 2007), and the NRY haplogroup O is common in populations residing in Asia and the Pacific (Kayser et al. 2003; Scheinfeldt et al. 2006; Underhill et al. 2000). When the same haplogroup occurs in two different areas, migration is assumed to have occurred. In particular, the geographic region (the region in which the sampled populations reside) where the haplogroup is most frequent and most diverse is often assumed to be the geographic location in which the haplogroup emerged.

These methods have inherent difficulties, however. Inferring the geographic location of past genetic events, such as the emergence and spread of a haplogroup based on present day haplogroup frequencies and distributions, assumes geographic continuity of past and present populations. This is particularly problematic in areas where climate change has resulted in major population shifts, e.g., the successive episodes of repopulation and depopulation in the Sahara since the last glacial maximum. In addition, characterization of haplogroup distribution and genetic diversity depends on adequate population sampling, as small sample sizes are unlikely to provide an accurate representation of haplogroup and haplotype frequencies, and sampling protocols must take care to avoid consanguineal kin, as an obvious example. Especially in the case of older samples included in haplogroup databases, sampling protocols are not always described. Where the population sample is inadequate and/or the assumption of geographic continuity of past and present populations is invalid, mtDNA and NRY haplogroup analyses can lead to erroneous conclusions regarding past migrations and gene flow.

\section{Autosomal Genetic Variation}

Over the past 10 years, it has become easier and cheaper to collect genomewide autosomal data. The advantage of genome-wide data is that they provide a more comprehensive picture of genetic variation (because they represent a much larger proportion of overall genetic variation than the mtDNA and NRY), but one of the challenges in using genome-wide data is that recombination severely complicates the reconstruction of genealogies for a given gene or region (patterns of recombination can actually be used in demographic modeling, and we provide an example further on using lactase persistence). Therefore, it is more difficult to infer the direction and timing of past migrations and gene flow. Additionally, many of the available sets of genome-wide autosomal variants (especially SNPs) are limited by the ascertainment scheme used (the way in which the variants were identified as significant and chosen for study). For example, many of the available genome-wide SNP arrays include variants that were identified in non-African populations, and it is unclear to what extent this ascertainment introduces a bias into the data and thus a bias into the application of these data to demographic inferences for African populations.

In the next section, we outline an example from Oceania illustrating how linguistic patterns and archaeological data have framed specific questions for genetic analysis about the source and path of population histories and migrations in Melanesia and Polynesia. This body of work illustrates contributions of genetic data to the study of population histories as well as limitations inherent to the use of genetic data. 


\section{Pacific Case Study: The Austronesian Expansion}

Sahul, the joined landmass of Australia and New Guinea during the low sea levels of the Pleistocene, was colonized by some of the earliest anatomically modern humans to leave Africa (Fig. 4). Migrants arrived in Papua New Guinea by 40-60 kya (dated with thermoluminescent and radiocarbon dating; Chappell et al. 1994; Groube et al. 1986; Roberts et al. 1995) and sailed (over the horizon) to the Bismarck Archipelago as early as 40 kya (dated with radiocarbon dating; Leavesley et al. 2002). These early inhabitants likely had sophisticated boating skills, practiced a coastal/marine lifestyle, and were able to utilize both terrestrial and marine resources using a relatively simple toolkit comprised of stone flakes, core tools and axes (e.g., Kirch 1997; Spriggs 1997; Summerhayes 2007).

Archaeological evidence demonstrates significant population movements subsequent to initial settlement within the region (e.g., Spriggs 1997). During the late Pleistocene (18-20 kya), non-native faunal remains appear at sites in the Bismarcks, and obsidian appears at distances as far as $350 \mathrm{~km}$ from its source (e.g., Kirch 1991; Summerhayes 2007), indicating regional trade and technological diversification. Additional technological innovations that emerged in the Holocene (4-10 kya) include tree cultivation and shell technologies (e.g., Spriggs 1997).

Not until roughly 3.1 kya is there evidence that people migrated into Remote Oceania (the region east of the Solomon Islands including the Reef Islands, Tikopia, Vanuatu, New Caledonia, Fiji, Samoa, and Tonga as well as other regions of eastern Polynesia and Micronesia) (Summerhayes 2007). The pottery found at these sites shares a distinctive dentate stamped style termed Lapita (e.g., Kirch 1997; Spriggs 1997). These sites also include faunal remains from non-native pigs, fish hooks, trolling lures, stone adzes, shell scrapers, peeling knives, anvil stones, shell rings,

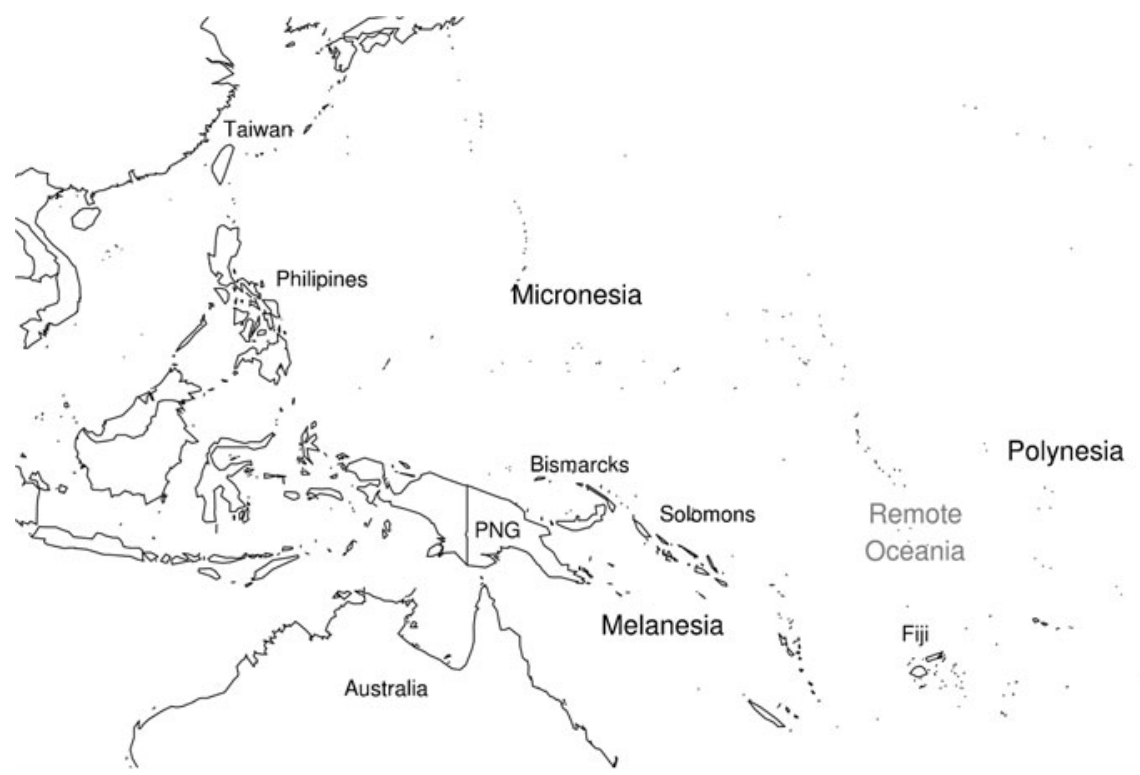

Fig. 4 Pacific map of areas mentioned in the text 
polishers, sling stones, discs, needles, tattooing chisels, and net sinkers (Kirch 1997; Spriggs 1997; Summerhayes 2007); however, some of these (e.g., pig remains) were found at earlier sites in the region ( $>6$ kya, reviewed in Summerhayes 2007). The Bismarck Archipelago is thought to be the location from which the expansion into Remote Oceania emerged because it contains the earliest Lapita sites ( 3.3 kya), which are at least 200 years older than Lapita sites in Vanuatu, New Caledonia, Fiji, and Polynesia (e.g., Kirch 2002; Summerhayes 2007). Some archaeologists interpret the pattern and distribution of Lapita pottery and the artifacts found at Lapita sites to support a long-range "out of Asia" model in which Neolithic Southeast Asian migrants arrived in Melanesia and rapidly spread into Remote Oceania (e.g., Diamond 1988; Kirch 1997). Others argue that most artifact technologies found at Lapita sites emerged in Melanesia, and the first migrants into Polynesia were primarily Melanesians (e.g., Terrell 1988; White et al. 1988). This scenario is one that can be tested with genetic data because the question to be addressed is relatively simple: What is the extent to which people moved from Southeast Asia into Melanesia and from either Southeast Asia and/or Melanesia into Polynesia. To evaluate this question, frequencies and distributions of haplogroups in samples from numerous populations in Southeast Asia, Melanesia, and Polynesia have been mapped. The clinal distribution of particular haplogroups may be a signature of past migration, and genetic diversity within haplogroups can be used to estimate the direction of past migrations as well as the time that has elapsed since these lineages were carried along with the migrating peoples.

The populations sampled speak either Austronesian or non-Austronesian languages. The Austronesian language family is estimated to have originated 5-6 kya in Southeast Asia (Pawley and Ross 1993). The contemporary residents of the Polynesian islands speak languages that belong to the Oceanic branch (containing 460 languages including all of the Austronesian languages spoken in Melanesia, Micronesia, and Polynesia). The linguistic data from the region have been interpreted to support the long-range "out of Asia" model of Austronesian expansion in which Neolithic Southeast Asian migrants speaking proto-Austronesian languages traveled rapidly through Melanesia and into Polynesia (Pawley and Ross 1993; Wurm 1967) with very little interaction with Melanesian inhabitants. Furthermore, linguistic evidence suggests that the proto-Oceanic branch of the Austronesian language family emerged in the Bismarck Archipelago prior to the colonization of Polynesia (Pawley and Ross 1993), which is consistent with the initial emergence of Lapita pottery in the Bismarcks. Non-Austronesian (or Papuan) languages are found primarily in Melanesia, with the largest concentration (some 800 languages) in highland New Guinea. The relationships among these languages are ancient ( $>20 \mathrm{kya})$ and thereby difficult to reconstruct (Dunn et al. 2005; Foley 1986; Pawley 2000; Ross 2005).

The earliest genetic studies focused on the distribution of mtDNA variation, and in particular the distribution of a 9-bp deletion (which defines Haplogroup B), that was interpreted to be a genetic marker of the "Austronesian expansion" since it is common in Southeast Asia but absent from highland New Guinea population samples (Hertzberg et al. 1989; Stoneking et al. 1990). More recently, mtDNA work (Melton et al. 1995; Redd \& Stoneking 1999) revealed the presence of an additional set of variants within haplogroup B that define a sublineage, termed the "Polynesian motif" due to the geographically restricted distribution of this lineage (it has not been 
found anywhere west of Indonesia, except in Madagascar, Fig. 5). Not only is the "Polynesian motif" a sublineage of haplogroup B and therefore a descendant of Haplogroup B, but an intermediate/precursor mtDNA lineage to the "Polynesian motif" (the "Polynesian motif" minus one mutation at position 14022) has been found in Southeast Asia [the populations with the highest mtDNA diversity within this intermediate lineage live in Taiwan (Merriwether et al. 1999)]. This geographic distribution of the precursor "Polynesian motif" and "Polynesian motif" variants is consistent with a west-to-east migration of Polynesian ancestors from Southeast Asia. The "Polynesian motif" is common throughout sampled Melanesia populations (although less so in some of the non-Austronesian speaking populations including the Ata, Baining, and Sulka (Friedlaender et al. 2007)) and is almost fixed (reaching $100 \%$ ) in sampled Polynesia populations. This distribution (west-to-east increase in the frequency of the "Polynesian motif") has been used to support the "out of Asia" model in which Southeast Asian Neolithic migrants rapidly spread through Melanesia and into Polynesia with very little gene flow.

However, more recent mtDNA studies (Pierson et al. 2006; Soares et al. 2011) based on whole mtDNA sequencing and analysis of the variation within the "Polynesian motif" lineage have resulted in a revised age estimate of the emergence of this lineage in the Bismarcks $(6,650,95 \% \mathrm{CI}, 4,500-8850$; and 6,950, $95 \% \mathrm{CI}$, 3,600-10,400, for maximum likelihood and complete genome clock molecular dating methods, respectively). Despite the wide confidence intervals, the combined results

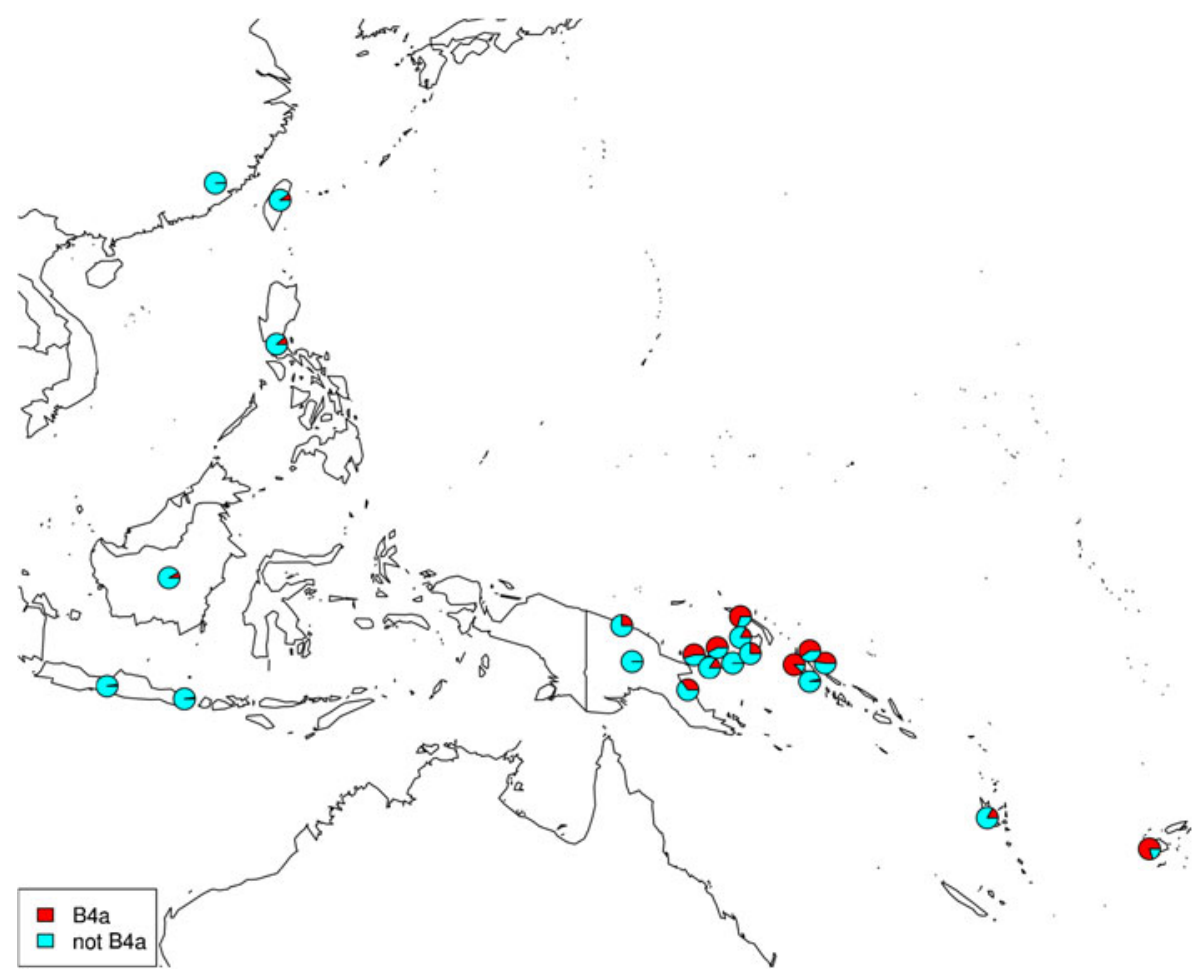

Fig. 5 mtDNA haplogroup B4a allele frequencies in the Pacific (data from Friedlaender et al. 2007) 
include evidence that it was present in Melanesia long before the emergence of Lapita pottery and Oceanic-Austronesian languages. The haplogroup may thus represent indigenous Melanesian and not recent Southeast Asian ancestry

These findings would bring the mtDNA data in line with Pacific NRY data, which is more consistent with archaeological interpretations of a primarily Melanesian origin of the migration into Polynesia with only occasional contributions from Southeast Asian migrants (Kayser et al. 2003). Specifically, haplogroup O, which is most common in SE Asia (ranges between 64 and 100 \%; Fig. 6), is not especially common among either non-Austronesian- (1.7\%) or Austronesian(11.1\%) speaking populations in Melanesia (Scheinfeldt et al. 2006). In addition, estimates of variation within the haplogroup O lineage are higher in Southeast Asia than either Melanesia or Polynesia (Capelli et al. 2001). The low frequencies of NRY haplogroup $\mathrm{O}$ in Melanesia and Polynesia are consistent with the high frequency of mtDNA haplogroup B in Melanesia and Polynesia, only if we accept that the "Polynesian motif" emerged in Melanesia long before the Lapita cultural complex. If recent Southeast Asian migrants were responsible for introducing the Lapita complex into Melanesia, the expectation is that the most common Southeast Asian mtDNA and NRY haplogroups would be well-represented in Melanesia, yet only the "Polynesian motif" is (Friedlaender et al. 2007). With the revised age estimate for the "Polynesian motif" in Melanesia predating the Lapita complex, the case for recent Southeast Asian origins for Lapita has been weakened.

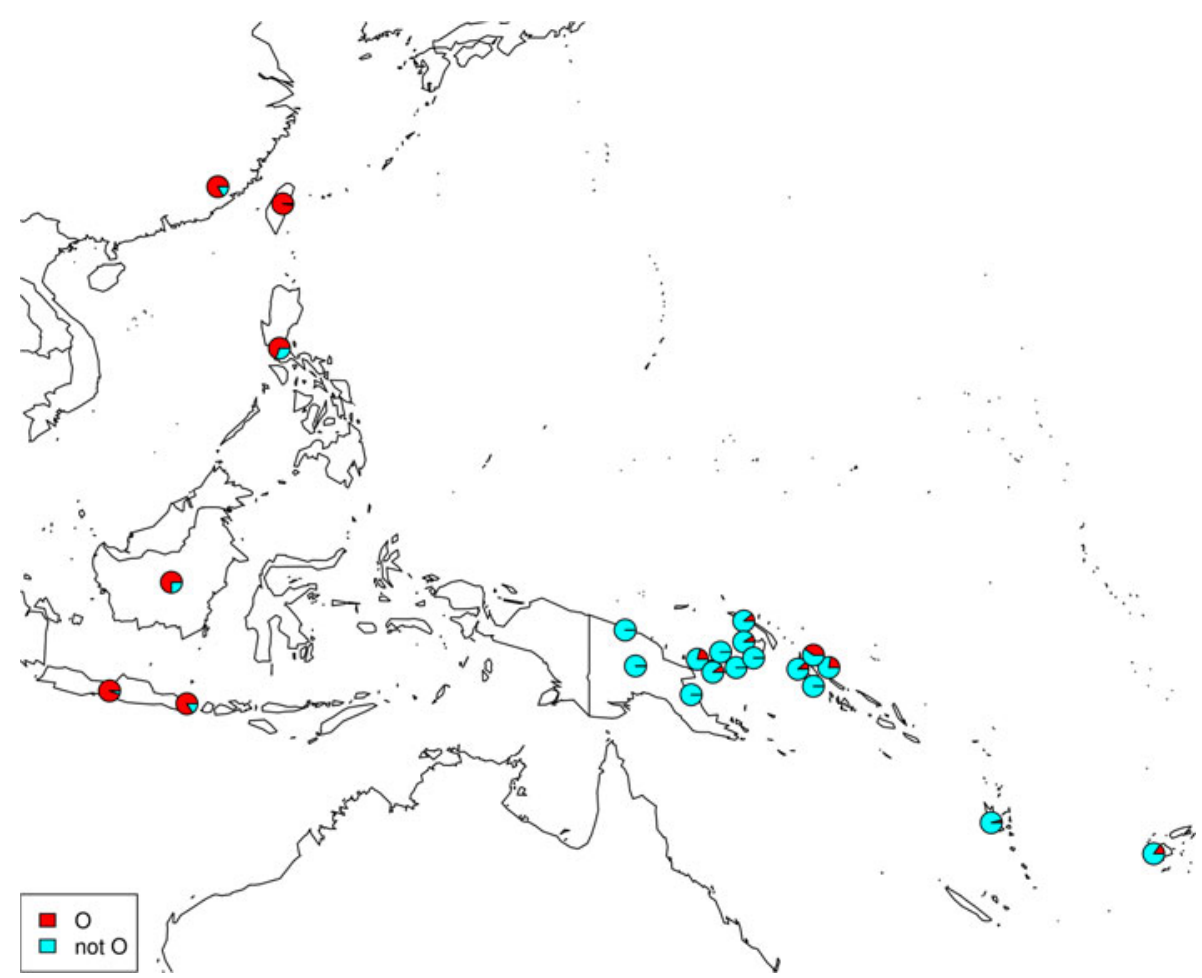

Fig. 6 NRY haplogroup O allele frequencies in the Pacific (data from Cox and Lahn 2006; Scheinfeldt et al. 2006) 
Since 2008, four genome-wide autosomal studies in the Pacific were reported. Kayser et al. (2008) focused on individuals from Polynesia and compared them with a Han Chinese population sample from Beijing and a population sample from Papua New Guinea. Kimura et al. (2008) analyzed genome-wide SNP data from a Papua New Guinea Gidra (Papuan) population sample and from a Polynesian population sample living in Tonga. Friedlaender et al. (2008) analyzed a genomewide set of autosomal markers in a larger Pacific sample including a larger regional sample from Melanesia to better understand the patterns of genetic variation within Melanesia. Finally, Wollstein et al. (2010) performed a genome-wide analysis of population samples from Papua New Guinea, Fiji, and Polynesia. If we combine the results from all four reports, we find low but detectable levels of past gene flow between Melanesians and Southeast Asians. These results are consistent with the mtDNA and NRY data from Melanesia and with the interpretation that the "Polynesian motif" was present in Melanesia prior to the emergence of the Oceanic branch of the Austronesian language family and Lapita pottery and therefore is not a marker of long-range, agricultural, Southeast Asian migrants.

With regard to the origins of the Polynesian expansion, however, the autosomal data do not agree with the combined mtDNA and NRY data that support a primarily Melanesian origin of the Polynesian expansion. While Kimura et al. (2008) inferred relatively large amounts (>50\%) of Melanesian ancestry in their Fiji population sample, Wollstein et al. (2010) and Kimura et al. (2008) both estimate roughly $30 \%$ Melanesian ancestry in their Polynesian population samples, Kayser et al. (2008) estimate that, on average, contemporary Polynesians share roughly $20 \%$ Melanesian recent ancestry, and Friedlaender et al. detected even less recent Melanesian ancestry (and this only from Oceanicspeaking Melanesians living in New Ireland). This discrepancy may be due to the fact that all of the autosomal studies included modest Polynesian population samples. Another possibility is that the past gene flow that is being detected with the autosomal data among Southeast Asians, Melanesians, and Polynesians occurred farther back in the past (well before $3 \mathrm{kya}$ ), consistent with a model proposed by Oppenheimer and Richards (2001).

Thus, the addition of more recent, higher resolution genetic analyses in the Pacific has contributed to a better understanding of population histories within Melanesia, where the population samples are relatively dense, including a better understanding of the degree to which Southeast Asian and Melanesian populations interacted with each other over the past few thousand years. However, recent genetic work has also resulted in additional questions regarding past migrations in Polynesia, where the population samples remain modest. Within Melanesia, we find relatively low amounts of shared recent ancestry with Southeast Asians, even in populations that speak Austronesian languages (e.g., Scheinfeldt et al. 2006), indicating a poor correlation between genetic and linguistic variation in Melanesia. With regard to the interpretation of the Lapita cultural complex in Melanesia, no simple model of innovation within Melanesia or intrusion from Southeast Asia can account for the pattern of genetic variation in the region. Rather, the genetic data are more consistent with models such as the "Triple I" model proposed by Green (1991) that includes innovation, intrusion, and integration to explain the emergence of the Lapita cultural complex in Melanesia. 
The study of Polynesian population histories is limited by the poor sampling included in the genetic studies, so it is more difficult to have confidence in any specific model of past migration; however, both the strict "out of Asia" model of migration (also known as the "express train" model, which allows for very little Melanesian involvement) and the strict indigenous Melanesian (which allows for very little southeast Asian involvement) can be rejected with the available genetic data (e.g., Kayser et al. 2008).

The Fulbe case study from West Africa that follows also revolves around questions of migration and population interaction (gene flow) that may be illuminated by a combination of archaeological, linguistic, and genetic analyses. However, the state of such studies is far more nascent in West Africa, where we will see that archaeology is plagued by poor documentation and vast gaps in even basic culture history, genetic studies are hampered by inadequate sampling, and linguistic approaches to the past of the relevant Atlantic language groups are completely undeveloped. In addition to outlining the current state of knowledge, we also present proposals for future interdisciplinary research.

\section{The Fulbe}

The Fulbe ethnolinguistic group, comprising $>10$ million people who speak Fulfulde languages, have traditionally had pastoral or agropastoral subsistence systems based on cattle and a distinct element of mobility, ranging from fully pastoral, to transhumance by youths who travel seasonally with cattle while older males farm, to seasonal movement by mixed farmers after the harvest (Abu-Manga 1999: 54). They have been historically documented for the past seven centuries, associated with continuous waves of migration by lineages that trace their origins back to the Middle Senegal Valley (Futa Tooro) (Fig. 7). From Futa Tooro, the Fulbe migrated to the Macina region of the Middle Niger and the Futa Jallon of Guinea by the fourteenth century. This movement may have been prompted by the southward push in the western Sahara of the Sanhaja/Azenagh Berbers seeking to avoid the Arab tribes (Ma'quil, Banu Hassan) that were consolidating gains in the thirteenth and fourteenth centuries (Norris 1986).

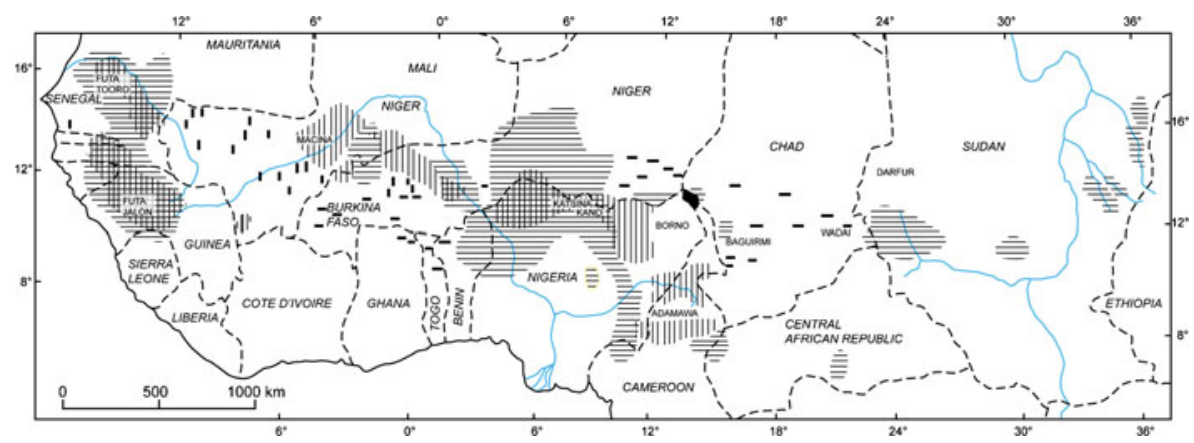

Fig. 7 Distribution of Fulbe populations: vertical lines show known precolonial distributions; horizontal lines show distribution in the nineteenth century (after Boutrais 1994, pp. 138-139) 
It is at this time that the Fulbe first appear in a European document: The 1339 map by Majorcan mapmaker Angelino Dulcert includes "Felle" (Fula) and "Tochoror" (Tukolor or Takrur), located to the southwest of Ganuya (ancient Ghana) (Roncière 1925, pp. 56, 114). The Tukolor historically are Fulfulde-speaking settled agriculturalists living in the Middle Senegal Valley (MSV) floodplain. It is not known how far back their Fulfulde linguistic identity extends, as the ethnic name references the early MSV polity of Takrur, of unknown linguistic affiliation, and several different ethnic groups claim historical presence in the MSV, including Serer and Soninke. The great eastward migration of Fulbe from the Macina began in the fifteenth century according to the Kano Chronicle, reaching Katsina and Kano by the 1460s and then Borno and Adamawa. By the seventeenth century, the Fulbe had penetrated to southern Darfur, via Baguirmi and Wadai (Braukamper 1993). In the seventeenth and eighteenth centuries, Islamized Fulbe traveled as itinerant scholars and marabouts; the eighteenth and nineteenth centuries saw expansionist jihadist movements led by Fulbe theocrats such as Seku Amadu, Usman dan Fodio, and Ahmadu Bello. Segments of Fulbe society became settled, while others retained the pastoral life of the Fulbe ladde (bush or nomadic Fulbe), of which the Wodaabe of Niger are the iconic example (Dupire 1962; Blench 1999). The nomadic Fulbe continued to spread by "migratory drift" (Stenning 1959), entering new areas to the south opened up by deforestation in the twentieth century as they sought to avoid colonial taxation. Some Fulfulde speakers moved back to the Futa Tooro from Macina under French rule.

The question of Fulbe origins has been the focus of considerable historical interest and speculation. European colonizers were impressed by the success of Fulfulde speakers in the eighteenth to nineteenth centuries in creating states and spreading Islam across a vast swath of the Sahel and savanna (Robinson 1975). In an era of racially framed historical scenarios, the distinctive physical appearance of the Fulbe prompted theories of distant origins; source areas in India, Malaysia, and Syria, as well as Ethiopia, the Nile Valley, and Libya have at various times been proposed (Brasseur and Brasseur 1981; Tauxier 1937), with claims of Hamitic affiliation prominently featured. Greenberg's $(1949,1963)$ definitive classification of Fulfulde as a West Atlantic language contravened such conjectures, and Murdock (1959) followed him in emphasizing the local emergence of the Fulbe in the vicinity of the Senegal Valley. Tauxier is still occasionally cited as the authority for Fulbe origins in the northeast (e.g., Cerny et al. 2006). Another source with a long shelf life is Dieterlen and Ba's (1966) intricate interpretation of certain scenes in the Tassili rock art as depictions of Fulbe rituals and ceremonies. The notion of a discernible Fulbe identity extending back millennia to the Central Saharan pastoralists had a number of adherents at one point (Simoons 1971, p. 435, note 18). Today, there is greater skepticism over the earlier interpretations of the rock art (Smith 2005, 136-137).

The Egyptian origin of the Fulbe was a central element in Cheick Anta Diop's influential work, The Cultural Unity of Black Africa (1959) as well as that of his main follower today at the University of Ch.A. Diop, A.M. Lam (De l'Origine Egyptienne des Peuls 2003). The Fulbe continue to hold a prominent place in discussions of the African past, reflecting in some cases their continuing ideological significance and the persistence of essentializing racial discourse. Online fora provide examples of the intense reactions that can be provoked by suggestions of non-African genetic ancestry in Fulbe populations. 
In the following section, we will review the evidence for Fulbe genetic history. One problem common to many of these studies is the reliance on the ethnic classification "Fulbe" as an analytic category for studies of local populations spread over a vast area. While a strong, common cultural identity and ideology characterizes all pastoral Fulbe groups, and a common language is spoken by a far wider diversity of Fulbe, their genetic history is strongly influenced by local patterns of intermarriage and shifting identity choices. We will outline some of the historical patterns after summarizing the genetic data, which support a fairly deep West African ancestry for Fulbe with scant evidence for an Egyptian or northeast African component. Both the mtDNA and NRY of sampled Fulbe populations have a low frequency of Eurasian lineages. In Fulbe populations from Mali, Cameroon, and Sudan, relatively high frequencies of the $-13910 * \mathrm{~T}$ allele associated with lactase persistence in Europeans provide additional evidence for gene flow from the Mediterranean basin, North Africa, or the Near East. Additional genetic analysis may help identify the route of introduction and chronology of this admixture. We then review the archaeological evidence relevant to Fulbe history, as we currently understand it. The state of currently available genetic and archaeological evidence is inadequate, but this can be remedied by rigorous interdisciplinary research with contributions from archaeology, bioarchaeology, genetics, and linguistics. We agree with Wylie (2002) that the most robust results are generated when different disciplinary investigations are structured to contribute diverse evidential elements that independently illuminate the research question at hand.

\section{Genetic Analysis}

As discussed earlier, genetic analysis is used to infer past population movements and biological affinities from spatial distributions of allele and shared haplotype frequencies, focusing on comparative genetic diversity and similarity or difference among tested populations. The earliest genetic analyses on Fulbe populations were done using classic protein polymorphisms - that is to say, the functional products of genes, such as Rh factors, and gamma-immunoglobins (Gm). Based on the Rh variant frequencies, Fulbe from Senegal were most similar to Afroasiatic speakers (e.g., Galla, Rendille, Amhara) in Ethiopia, but clustered with West African groups when Gm variant frequencies were plotted (Excoffier et al. 1987; Blanc et al. 1990). In addition, Cavalli-Sforza et al. (1994, pp. 181-182) studied classic protein polymorphisms and showed that Serer, Wolof, and Fulbe in Senegal form a discrete genetic cluster. However, since these factors are subject to natural selection, similarity in frequencies may reflect similar selection pressures rather than close genealogical relationship.

\section{MtDNA and NRY Studies}

Only in the last few years has the technology for rapid and cost-effective DNA sequencing become available, permitting relatively high resolution studies using many genetic markers (e.g., Cerezo et al. 2011; Barbieri et al. 2012). Much of the earlier literature on mtDNA and NRY analysis in Africa is of lower resolution, with 
only broad patterns of genetic variation revealed. Although the sampling of West African populations in general and the Fulbe in particular is problematic - characterized by small samples and undocumented collection protocols as well as serious gaps in geographic and population coverage - nevertheless, certain patterns are of interest.

MtDNA studies demonstrate the similarity of Fulbe populations in Guinea Bissau and Senegal to their neighboring northern Atlantic speakers-Wolof and Serer (Rosa and Brehm 2011). Furthermore, Fulbe mtDNA haplogroup frequencies are markedly similar in all sampled Fulbe groups from the Atlantic coast to the Chad Basin. The dominance of West African mtDNA lineages L1b/b1, L2c, and L3b/d affirms that maternal inheritance in the Fulbe is decidedly West African (Cerezo et al. 2011; Cerny et al. 2006, 2011; Gonzalez et al. 2006; Rosa et al. 2004-it should be noted that these haplogroups have time depths of between 120,000 and 60,000 ya [Underhill and Kivisild 2007] and may have expanded from LGM refuge areas into the Sahara during the early Holocene wet period). Variable but low frequencies of North African haplogroup U6, thought to be related to a southward expansion of the Berbers, occur particularly in the western Fulbe samples and also at higher frequencies among their northern neighbors, the Maure (Gonzalez et al. 2006; Rosa et al. 2004). These may indicate a north-south route for gene flow along the northwestern margin of Africa. In addition, Eurasian haplogroups (e.g. U5, J1b, and V) that have spread to North Africa are variably present in low frequencies in most sampled Fulbe groups (Cerny et al. 2006; Rosa et al. 2004).

Early mtDNA studies sampled settled Fulbe (Rosa et al. 2004; Scozzari et al. 1988; Watson 1996, 1997), who tend to resemble neighboring settled populations. Cerny et al. $(2006,2011)$ demonstrated that, by contrast, the mtDNA and NRY of nomadic Fulbe sampled in several countries from Mali to Chad differs from that of neighboring farming populations, as well as previously sampled populations of settled Fulbe, Wolof, and Serer. Unfortunately, nomadic Fulbe from Senegal have never been sampled adequately, so we do not know the extent to which the migrants resemble that putative source population. With the exception of the Songhai and Fulbe in Mali, farmer and pastoralist groups shared very few haplotypes, demonstrating a lack of gene flow between these two groups (Cerny et al. 2011). Gene flow among pastoral Fulbe, despite the distances involved, appears to be extensive.

Y chromosome studies have benefited from recent advances in mutation detection technology and phylogeographic methodology, permitting dramatic increases in both haplogroup recognition (from 153 in 2002, to 311 in 2008; Karafet et al. 2008), and genealogical resolution as additional markers within haplogroups have been identified. One result has been the renaming of certain NRY lineages as the sequence of genetic differentiation has become clearer. This means that earlier and more recent studies may use different names for the same lineages. For the purposes of this discussion, we reference haplogroups with the nomenclature provided in Karafet et al. (2008), and we use the lineage/sublineage alphanumeric label followed by the defining basal SNP mutation for clarity. Unfortunately, most of the West African studies predate these advances in lineage and sublineage definition, so the degree of resolution is very low and often inconsistent across studies. It is possible to say only that West African Fulbe are characterized, along with almost all sub-Saharan West African populations, by a very high relative frequency of haplogroup E1b1 (PN2) and several of its sublineages (Fig. 8) - 
Fulbe NRY Haplogroup Tree

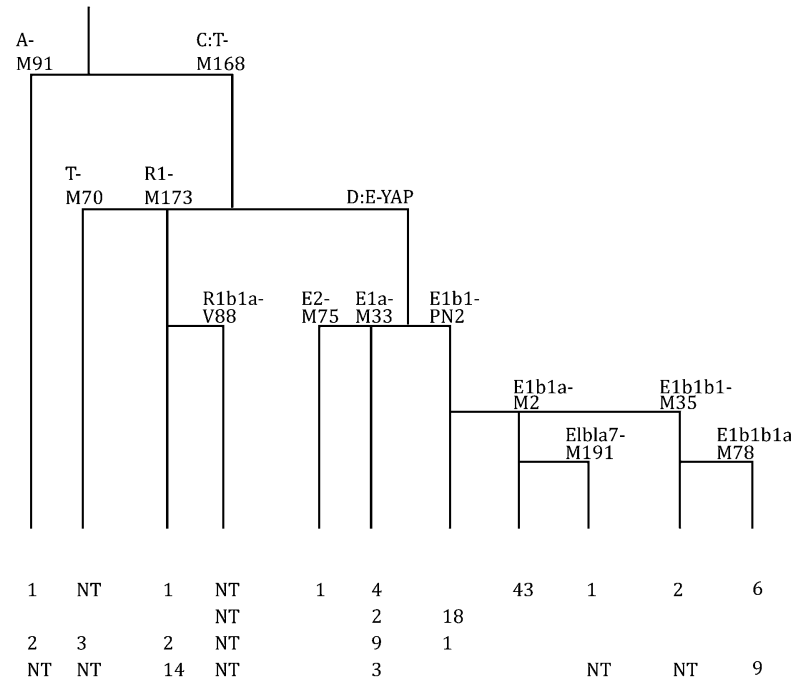

Fig. 8 Fulbe NRY haplogroup tree. Four population sample haplogroup frequencies are displayed: Guinea-Bissau (Rosa et al. 2007), Burkina-Faso (Cruciani et al. 2002), Cameroon (Cruciani et al. 2002), and Sudan (Hassan et al. 2008). SNP lineages that were not tested in a particular study are labeled NT

80-90 \% in Fulbe samples from Senegal (Semino et al. 2002 pooled with other Senegal populations), Burkina Faso (Cruciani et al. 2002), and Guinea Bissau (settled Fulbe-Rosa et al. 2007). In addition, Cerny et al. (2011) report that most of the STR haplotype clusters identified in samples from pastoral Fulbe from Mali, Burkina Faso, Niger and Chad are referable to two sublineages of E1b1 (PN2) defined by the M2 (common in West and Central Africa) and M35 (more common in northern and eastern Africa) SNPs.

The only other haplogroups reported in West African Fulbe samples are E1a, E2, A, and R1, all at frequencies of $\leq 10 \%$ (Cruciani et al. 2002; Rosa et al. 2007). The last haplogroup, R1, is common in Europe and is particularly geographically structured across sampled Fulbe (Cruciani et al. 2010): 1 \% in West African Fulbe, $11 \%$ in Fulbe from Cameroon, and $54 \%$ in Fulbe sampled in Sudan (Hassan et al. 2008). A sublineage of R1, R1bla (V-88), is thought to have entered north Africa 5-11 kya, where it is still present in low frequencies, but has reached notably high frequencies in the central and eastern Sudan, and appreciable frequencies in a Fulbe population sample from Niger (14\%) as well as in northern Berbers and Arabs (3-27\%; Cruciani et al. 2010). Figure 8 summarizes the main differences among the Ychromosome haplogroups of western, central (Cameroonian), and eastern Fulbe populations. These are considerable, and they shed light on some aspects of the recent population history of the Fulbe. We will return to this after considering the autosomal data.

\section{Genome-Wide Autosomal Studies}

In a landmark study, Tishkoff et al. (2009) studied over 1,300 microsatellite (STR), indels, and SNPs from across the autosomal genome for 113 African population 
samples. The authors used the software package STRUCTURE to estimate the relative proportions of genetic ancestry for each individual without any a prori information related to geography or ethno-linguistic identity. STRUCTURE is a Bayesian method that divides each individual into one or more genetic groupings called ancestral allele clusters (AACs). Each vertical bar in the STRUCTURE graphic represents a single individual, and heterogeneous ancestry is indicated by differentcolored AACs. The West African samples from the savanna and forest generally are the least heterogeneous, with primarily AACs shared with other speakers of languages belonging to the Niger-Congo/Kordofanian language family (Fig. 9, shown in orange). In Cameroon, AACs shared with Chadic and Central Sudanic speaking populations (maroon) are significant. In addition to moderate levels of shared AACs with other Niger-Kordofanian speakers, the Fulbe from Nigeria and Cameroon have a striking incidence of a distinctive AAC (fuschia) that is shared in moderate to low levels with the Mozabite sample from northern Algeria and the Mandinka sample from Senegal. The Adamawa Fulbe, who have settled and become farmers, show considerable mixing with neighboring populations, such as Hausa and Baggara (Shuwa) Arabs. The Mbororo pastoral Fulbe, however, show far less admixture, consistent with the observations of Cerny et al. (2006, 2011). European/Middle Eastern AACs (blue) are found in low frequencies in most West African populations, including the Fulbe, but are of course more numerous in the Baggara Arab population.

More recently, ADMIXTURE analysis (a clustering program similar to STRUCTURE) by Henn et al. (2012) suggests an absence of northeast African ancestry among the Fulbe (pastoral Wodaabe from Nigeria were sampled), and confirms a mixed sub-Saharan and northwest African (possibly Berber) ancestry, possibly of some antiquity (Fig. 10).

From the genetic data available in these studies, several aspects of Fulbe population history can be highlighted. First, most of the Fulbe sampled across West Africa
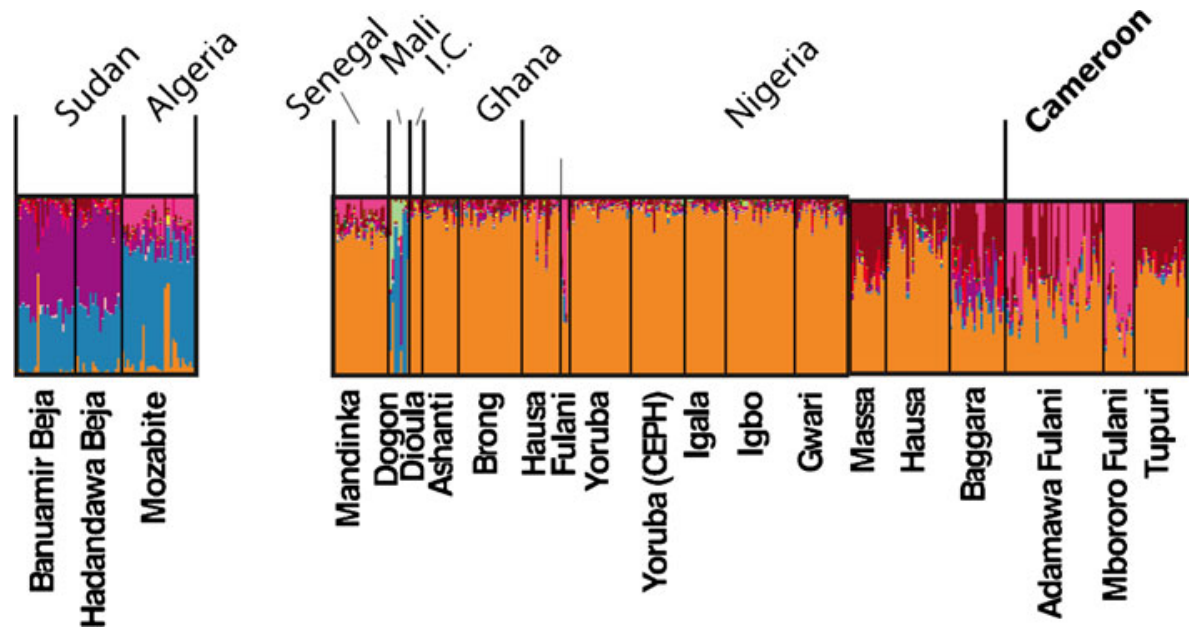

Fig. 9 STRUCTURE plot of ancestral allele clusters (AAC) for sampled populations in North Africa and West Africa. Each vertical bar represents an individual (from Tishkoff et al. 2009, Fig. 4, reproduced with permission of the AAAS). This figure appears in color in the online version of this article 


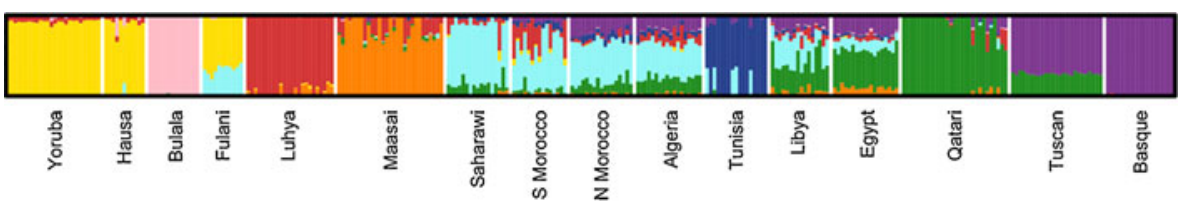

Fig. 10 ADMIXTURE plot of population structure of North African and neighboring populations (taken from Henn et al. 2012, Fig. 1). This figure appears in color in the online version of this article

are drawn from a West African mtDNA gene pool. The incidence of European or North African mtDNA lineages is quite low. Fulbe Y chromosome diversity is geographically structured, however. Western Fulbe generally resemble other West African populations, while Central and Eastern Fulbe groups testify to gene flow due, at least in part, to the recruitment of males from Central and Eastern Sudanic neighboring populations, a pattern that is particularly striking in the NRY sample from Fulbe in Sudan (comparable mtDNA data are not available for the eastern Fulbe). Given the recent arrival $(<400$ years) of the Fulbe in the central and eastern Sudan, this pattern is likely to be of recent date. With evidence in hand for local and regional differences in gene flow among settled vs. pastoral Fulbe, and western vs. eastern Fulbe populations, the temptation to extrapolate results from one or two sampled populations to all Fulbe (e.g., Hassan et al. 2008; Tishkoff et al. 2009, supporting material, p. 16) should be resisted. Fulbe genetic history is marked in certain areas by significant population mixing, intermarriage, and shifts in ethnic identity in recent centuries, as we outline in the next section. This has implications for the kind of population sampling that needs to be done if we are to achieve the finer resolution that will take us from macro- to meso-scale inference and better alignment with archaeological data and priorities.

\section{Discussion}

To conclude the review of available genetic studies on the Fulbe, we would emphasize the importance of incorporating into research design and genetic sampling protocols the evidence of recent population history and marriage practices. Some genetics researchers have been aware that language boundaries are permeable and even strict endogamy rules get broken (e.g., Blanc et al. 1990; Coia et al. 2009; Spedini et al. 1999), while others have seemed oblivious to the importance of understanding the history and culture of their linguistically categorized objects of study. Genetic analysis has demonstrated that endogamy is more strictly observed by pastoral than by settled Fulbe (Cerny et al. 2006, 2011). Along the Senegal Valley, pastoral Fulbe women are reportedly never given in marriage to non-pastoralists (Kyburz 1994:54). Once Fulbe become sedentary, however, gene flow with neighboring settled populations increases (Dupire 1994).

In the context of the nineteenth-century Fulbe theocratic states established across the Sahel, political power in some cases resulted in "Fulbeization" of local populations, including former slaves who adopted the Fulfulde language and, to varying degrees, Fulbe identity (Schultz 1984; Keita et al. 2010). This has 
also operated in the reverse sense-Fulbe have been assimilated by Hausa in parts of northern Nigeria (see Blench 1990 for details on the local complexities of Fulbe identity and language in Nigeria). Further east, Fulbe frequently intermarry with Baggara Arabs, who abandoned camel-rearing and adopted the mixed cattleherding/millet cultivation economy of the Fulbe, while maintaining their Arabic language (Abu-Manga 1999, p. 53; Braukamper 1993). This intermarriage is reflected in the STRUCTURE autosomal data analysis (Fig. 9). This raises the important question of gene flow among different pastoral groups. The Fulbe have historically lived in proximity to other pastoralists: Berbers and Maures in the western Sudan, Tuareg in the west-central Sudan, Koyam and Shuwa in Borno, Teda in Chad, Baggara Arabs in the central eastern and eastern Sudan. Particularly in times of epizootics (such as the great rinderpest and bovine pneumonia epizootics in the nineteenth century) and drought, when herd losses are catastrophic, intermarriage and assimilation with other pastoral groups may provide a way to maintain a pastoral way of life and, in the case of other cattle herding groups, to rebuild herds through bridewealth payments in livestock. These examples are fully consistent with our understanding of ethno-linguistic identity as fluid and situational (Barth 1969) and contradict any reified notion of "the Fulbe" as an analytic category for which genetic observations on one population can be applied more broadly to the entire group. For this reason, anthropologists have repeatedly cautioned against treating gene history as ethno-linguistic history (Brown and Pluciennik 2001; Keita et al. 2010; MacEachern 2000).

The guiding notion of genetic studies of population history is that gene/allele distributions are "structures" that reveal aspects of history. However, the interpretation of historical process from genetic patterns depends on the models used, as seen in the Pacific case study previously discussed. These in turn depend significantly on "one's understanding of the biology of the traits, social processes and histories of the region" (Keita 2005, p. 139). Genetic sampling, in addition to targeting underrepresented groups and geographical areas, should pay much more attention to the collection of historical data along with their blood or saliva samples, including recent family histories and migration routes and intermarriage patterns (Keita et al. 2010). As the resolution of phylogeographic analysis becomes increasingly refined with regard to both timescale and distribution of novel genetic variants, meaningful interpretation will require concomitantly fine-grained local and regional historical data and population data sets adapted to the geographic and historical scale of the events under investigation (Coia et al. 2009). For archaeologists, the difficulty with phylogeographic approaches is that distributions of modern genetic diversity across geographic space are palimpsests of many layers of gene flow and drift resulting from a variety of cultural and historical processes - and it is precisely these processes, which need to be teased out at a fairly high degree of temporal resolution, that are of primary interest (Brown \& Pluciennik 2001; MacEachern 2000). The genetic data that have been available until recently for interpreting Fulbe population history are very blunt tools for the kind of analysis needed. As more intensive sampling protocols reveal regional population structure, and more informative genetic markers are identified; however, the resolution of genetic studies will continue to increase, generating more detailed insights using mtDNA, NRY, and genome-wide autosomal data. 


\section{Archaeology and Fulbe History}

Clear and unambiguous evidence for the Fulbe extends no further back than the historical documentation in the fourteenth century. Archaeological identification of the pastoral Fulbe is difficult due to their very low archaeological visibility (MacDonald 1999) (Fig. 11). Their material culture is notably ephemeral in the Sahel, with a predominance of organics such as animal skin, grasses, and calabash (Smith 2005). Based on ethnohistoric observations, we might conclude that the Fulbe would be primarily visible archaeologically as palimpsests of dung deposits from livestock pens, and ash and debris from fires for cooking and keeping insects at bay. With such limited evidence for material culture, and absent a unique Fulbe pottery industry (pastoral Fulbe purchase any pottery they may use from settled populations, e.g., Gueye 1998, p. 116), it is not an easy proposition to use the direct historical method to trace the Fulbe backwards in time from the present. The only ethnoarchaeological study conducted on Fulbe occupation sites focused on settled groups in Cameroon (David 1971) and included a caveat that the observations could not be extrapolated to mobile Fulbe groups.

What we do not know is how far back in time the historic Fulbe pattern of high mobility and low archaeological visibility extends. It is possible that their specialized pastoralism, which depends crucially on the exchange of dairy products for grain and other subsistence and craft items, is a fairly recent phenomenon. Most theories of the origins of this type of symbiotic pastoralism involving herders and farmers who form a single economic unit see it as a later development out of mixed farming, enabled by the development of markets, complex social organization, and interregional contacts (Anfinset 2010, Ch. 5; Sadr 1991, pp. 5-11).

Based on the recently established archaeological sequence covering the period 2500-1000 BP in the Futa Tooro traditional homeland of the Fulbe, we propose that the ethnohistoric Fulbe pastoral system first developed out of an earlier agropastoral economy in the late first/early second millennium $\mathrm{CE}$, when reliable agricultural surpluses first became available in the Middle Senegal Valley and there was a rapid

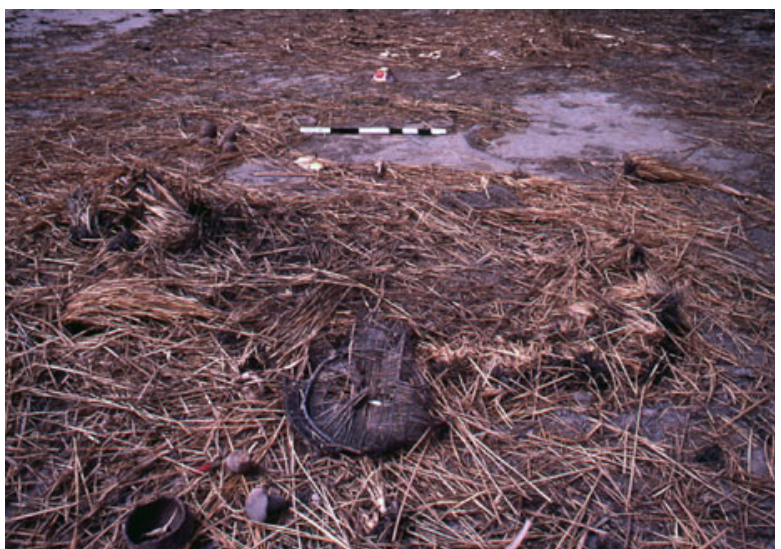

Fig. 11 Recently abandoned Fulbe pastoral camp near Djenné, Inland Niger Delta, Mali. The scale marker is $20 \mathrm{~cm}$ long, and it is placed in the interior area of what was a straw hut. Other than burnt areas where cooking fires were lit, there is little durable material evidence of the site's occupants 
development of markets and political complexity. Focusing on the archaeology of northern Senegal/southern Mauritania provides our best opportunity to study the context and trajectory of the historical emergence of the Fulbe, we suggest, in view of Futa Tooro's key role in Fulbe history, genetic evidence for West African ancestry, and the classification of Fulfulde as a North Atlantic language closely related to Serer and Wolof. We provide an overview of available evidence for settlement and economy in the Middle Senegal Valley beginning with its initial occupation by agropastoralists ca. $2500 \mathrm{BP}$ at a time of increasing aridity (Fig. 12) (McIntosh et al. 2012).

Agropastoralists from the north colonized the levees of the central MSV at this time. They occupied the site of Walalde from 2500 BP (800-400 cal BC) to $2200 \mathrm{BP}$ (400-200 cal BC), creating a 5-ha mound with deposits up to $4.5 \mathrm{~m}$ deep. It represents fairly intensive occupation by people who consumed (and presumably herded) primarily cattle and some small livestock, occasionally hunted wild antelope and fished on a very limited basis (Deme 2003; Deme \& McIntosh 2006). Domesticated millet (Pennisetum glaucum) dominated the macrobotanical remains (Murray \& Deme in press). Dozens of small, terracotta horned figurines were found, many in apparent association with burials; these are interpreted as schematic representations of short-horned cattle (Fig. 13), signaling the kind of symbolic investment in cattle that we associate with pastoral societies such as the Fulbe. A small number of struck lithics in the earliest deposits, accompanied by iron tools, suggests that technology at the site was in transition from stone to iron. Abundant iron production debris (tuyeres, slag) was recovered from the upper deposits (400-200 cal BCE).

The precursors of and regional context for Walalde are poorly known. Agropastoralists with a millet and livestock-based economy inhabited sites on the dhar and baten (plateau and lake) landscape around Tichitt and Walata/Nema for over a thousand years until increasing aridity resulted in abandonment of the stonebuilt settlements on the dhar ca. 1000 BCE. Little is firmly established regarding the development of these societies or their subsistence economies during this period.

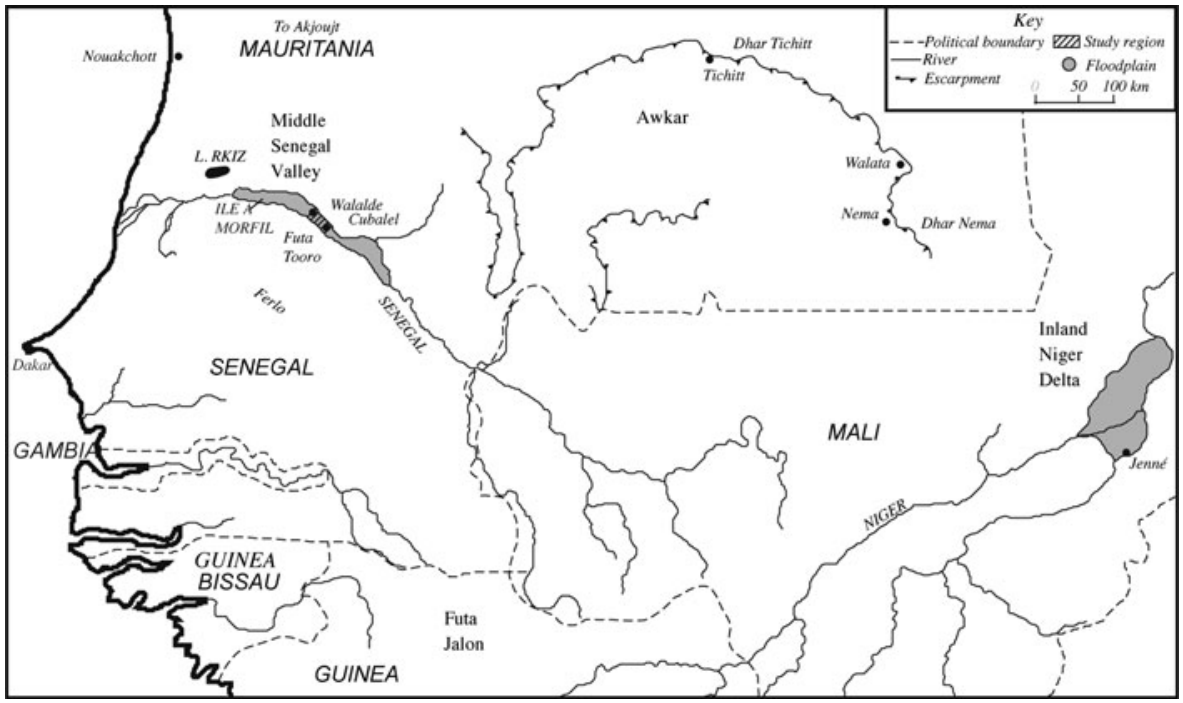

Fig. 12 Map of sites and regions mentioned in the text 

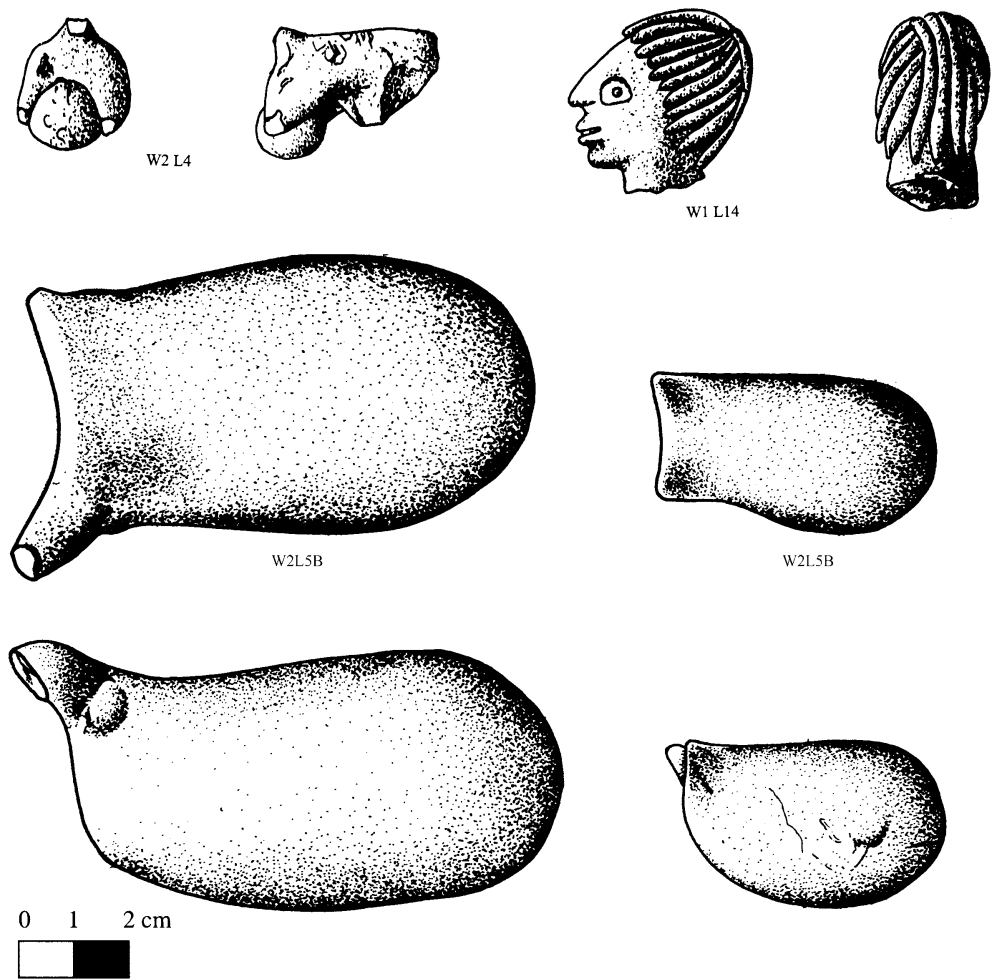

Fig. 13 Horned terracottas from Walalde. The human head is also of great interest (from Deme \& McIntosh 2006, p. 334)

Munson's (1971) pioneering efforts to develop a ceramic sequence based on excavated and ${ }^{14} \mathrm{C}$-dated assemblages were not pursued and refined by subsequent researchers, with the exception of recent research around Dhar Nema (MacDonald et al. 2009). Most of the published information seems to be based on deflated surface collections and ${ }^{14} \mathrm{C}$ dates of uncertain association (Amblard-Pison 2006). However, one pattern of interest for our purposes can be highlighted from Munson's work. Between 2800 and $2100 \mathrm{BP}$, there was a major shift in the pottery assemblage. The earlier "classic" Tichitt assemblage dominated by simple round bottomed bowls was largely replaced by everted rim jars (Munson 1971; MacDonald et al. 2009). New decorative motifs appear that link the first millennium BCE Tichitt assemblages with the earliest agropastoral assemblage at Walalde, as well as with pastoral assemblages around Bouhdida on the Atlantic coast (Deme and McIntosh 2006; Vernet 2001). These distinctive motifs include long, or "running" comb [long, straight lines of crisp impressions that suggest a tool at least $5 \mathrm{~cm}$ long-perhaps a twine wrapped knife such as the furgu used today by the Tukolor (Gueye 1998)], zoned comb impression (zones delineated by incision and filled with straight or rocker-comb), guilloche cordons, and "lozenge" motifs consisting of an incised oval with incised or impressed fill) (Munson 1971; Amblard Pison 2006: pp. 184, 198, 205, 207; Vernet 1993) (Fig. 14). 


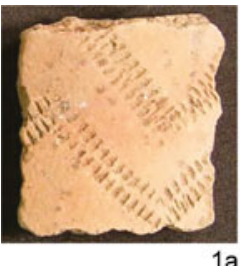

$1 \mathrm{a}$
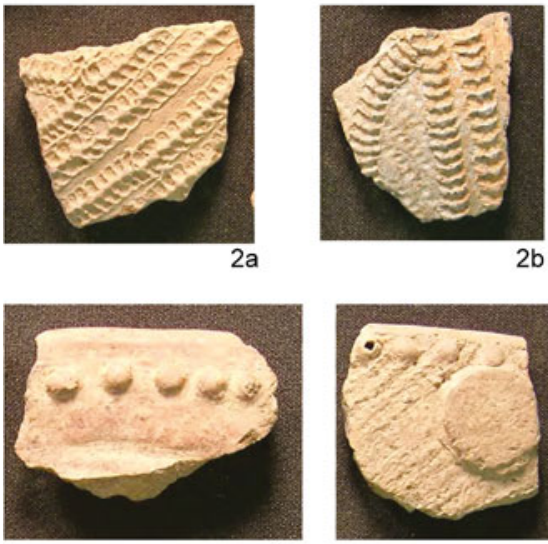

$3 a$
$2 b$

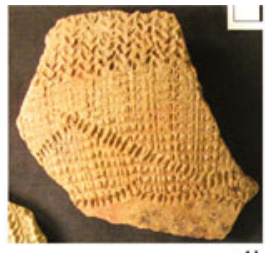

$1 \mathrm{~b}$

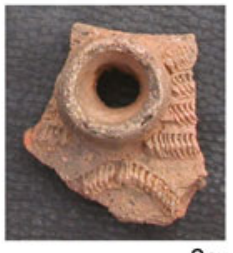

2c

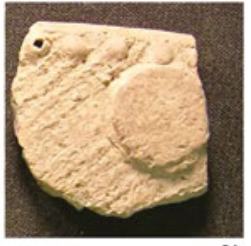

$3 b$

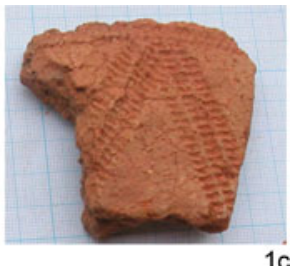

$1 \mathrm{c}$

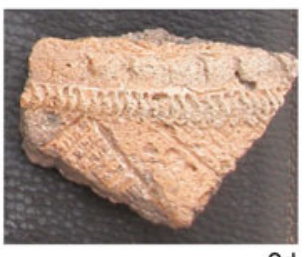

$2 d$
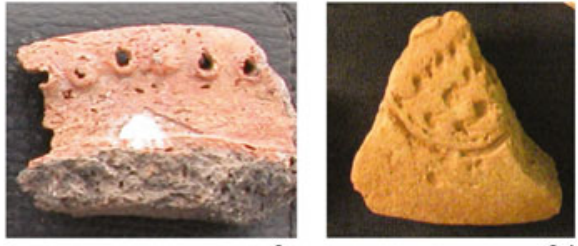

$3 d$

Fig. 14 Shared, distinctive ceramic decorative styles and motifs from Walalde, the Nouakchott area (Imbich Est) and the Lake Rkiz area: "running comb" from Walalde $(1 a, b)$ and Lake Rkiz (1c); guilloche from Walalde $(2 a, b)$ and Imbich Est $(2 c, d)$; outpressed nubbins from Walalde $(3 a, b)$ and Imbich Est $(3 c)$; partial lozenge motif (Walalde 3d) (photos of sherds from Mauritania courtesy of R. Vernet)

The Bouhdida surface assemblage from Imbich Est has been described in some detail (Vernet 1993, 2001), permitting identification of its affinities with Walalde pottery. Dated ca. 2600-2200 BP, these sites were apparently occupied by cattle herders who also fished and used both stone and copper tools (Vernet 1993). The source for the abundant copper assemblage was Akjoujt, located $<100 \mathrm{~km}$ away. Akjoujt copper was also documented at Walalde, where copper earrings had the arsenic-rich compositional signature of that copper source (Deme \& McIntosh 2006). Based on the distribution of surface copper artifacts recovered in Mauritania, Deme \& McIntosh (2006) suggest that copper moved with and among pastoralists who pastured herds seasonally in the interdunal depressions of southwest Mauritania; close affinities between Walalde and the Lake Rkiz area have also been noted (Deme \& McIntosh 2006). Contact-likely indirect-between Boudhida and Walalde and North Africa is indicated by copper earrings at both sites in a Punic style known from jewelry in Moroccan graves of the eighth to sixth centuries BC (cp. Deme \& McIntosh 2006, p. 335; Jodin 1966, p. 71; Ponsich 1967, pp. 34, 91, 196; Vernet 1993, p. 347).

Increased interaction with the north may have involved gene flow. Munson and others suggest that the appearance of two-wheeled chariots and horses on the rock engravings in Mauritania probably signals the arrival of Berber language speakers at about this time. While we have no information on the physical anthropology of the makers of Bouhdida and Tichitt pottery in the mid-first millennium BCE, analysis of the one intact Walalde cranium indicates a definitively sub-Saharan morphology (Ribot 2011). 
The arrival of agropastoralists in the MSV ca. 2500 BP correlates broadly with a decline in the number of archaeological sites in southern Mauritania (Bathily et al. 1998) and a period of fluctuating climate trending towards greater aridity. Walalde is the only MSV site currently documented from the first millennium BCE. A multiseason project of intensive survey and excavation at 11 sites in the same sector as Walalde has provided initial insights into the continuation and development of agropastoral societies during the first millennium CE (McIntosh et al. 2012). The focus of the project was a $460-\mathrm{km}^{2}$ area centered on the village of Cubalel in an interior floodplain known as the Ile à Morphil, within the broad area historically attributed to the early polity of Takrur. Within this study region, sites were distributed primarily on the 9-10-m-high levees that generally remain above the annual floodwaters. Sites can be categorized as mounds (0.5-5 $\mathrm{m}$ of accumulation) and flat surface scatters. Mounds occur only on the levees, and generally range in size from $1 / 2$ to 4 ha. Only a handful of sites exceeded that, reaching 12 ha exceptionally. Excavations at both mounds and flat scatters revealed subsurface deposits from a series of occupation and abandonment episodes.

The mounds were built up of domestic debris associated with wattle and daub houses, and hundreds of burnt features, including hearths, ashpits, and burnt wall material. The frequent burning anchored and helped to consolidate the otherwise easily eroded sandy loam deposits. The mound with the most extensive accumulation - C3 - provided a sequence that covered most of the first millennium $\mathrm{CE}$, and the changes in material culture documented there were confirmed at the other Cubalel mound sites also occupied during the first millennium. All in all, 36 radiocarbon dates anchor the sequence at eight sites. The pottery assemblage changes rather rapidly through time, making it an excellent chronological tool.

The overall pattern of the archaeological evidence in the Cubalel region throughout the first millennium CE is consistent with semisedentary agropastoralists living for extended episodes on the high levees. Repeated construction and decay or burning of wattle and daub structures resulted in rapid mound accumulation, despite episodes of mound abandonment. The relation of flat sites to mounds needs a great deal more investigation, as surface collection and excavation focused almost exclusively on the latter. Test excavation at one of the flat sites revealed deposits extending down $0.85 \mathrm{~cm}$ with numerous ash-pits and hearth-like burned features, dating to $600-800 \mathrm{CE}$. The pottery was no different in appearance or quantity from that found in contemporaneous mound site deposits.

Subsistence at all sites appears to be generalized, with primarily domestic animals and cereals, but significant hunting, fishing, and gathering of wild plants. Dog bones are frequently charred, suggesting consumption. The emphasis in the faunal assemblage shifts from cattle at Walalde in the first millennium $\mathrm{BC}$ to sheep and goat at Cubalel sites in the first millennium CE. The reasons for the shift may have to do with altered consumption practices and/or changed climate circumstances - but it is noteworthy that the dominance of ovicaprids continues despite the return of wetter conditions later in the first millennium CE. The cattle at all sites are in the middle size range recognized by MacDonald and MacDonald (2000, p. 131), comparable in size to modern Ndama breeds, although one very small specimen (West African dwarf shorthorn size category) was recorded from Walalde (C. Cain, in Deme 2003). 
Flotation was systematically undertaken in every level and pit feature. Pearl millet is present at all sites as the primary domesticated cereal crop, accompanied by very low but consistent levels of fonio. Sorghum, cultivated in the clay basins of the floodplain as a flood recession crop historically in the MSV, is notably and surprisingly absent in all sites and levels prior to the end of the first millennium. It would appear that the floodplain basins were largely used for pastureland during this period. This finding has significant implications for agricultural productivity and the possibility of grain surpluses, which historically have come from the double cropping of millet and sorghum that is uniquely possible in the floodplain. Grain surpluses, in turn, are a crucial factor in specialized pastoral systems that are based on the exchange of milk products for grains and craft items.

Site size remained very small and site density low in the study region for the first seven centuries of the first millennium CE, suggesting that subsistence productivity was low. The near-exclusive reliance on millet would have involved a significant segment of the population in cultivation on the levees during the summer rainy season. At this same time, another segment (young men?) would have moved the livestock both to seek higher quality forage and to keep the cattle away from the fields. This type of system produces labor bottlenecks (for weeding and harvesting millet) that limit subsistence productivity (Swift 1979). A notable increase in site density and site size in the late first/early second millennium likely reflects the resolution of these labor constraints through increased specialization, which became absolutely essential when décrue cultivation of sorghum began. Full-time farmers in the floodplain could retain their traditional agropastoral identity by outsourcing herd transhumance to specialized pastoralists, as do the Tukolor. More options for longer seasonal transhumance may have become available with the emergence of political structures capable of assuring safe passage for herds. In this way, both the pastoral and agricultural sectors of the MSV economy could expand. The use of slaves (jeyabbe) in the agricultural sector was important for surplus production historically (Robinson 1971, p. 26), but we do not know how far back in time this goes.

This hypothetical outline posits that food-producing economies in northern Senegal shifted over the past 3,000 years from more generalized agropastoral subsistence economies that incorporated wild components where opportunities existed, to more specialized economies, including that of the pastoral Fulbe, in the past millennium. Alternatively, broad spectrum consumption patterns may reflect the operation of local subsistence exchange systems linking specialist herders with fishers, cultivators, or hunter/collector specialists (McIntosh 1993). Given the diverse dimensions of local subsistence systems, either is a possibility. Determining which model is a better fit for the development of subsistence systems in our focus area will require high-resolution, problem-oriented archaeological research that is grounded in more extensive excavation and survey within regionally focused projects. Special attention must be paid to the identification of specialized, highly mobile pastoralists archaeologically. Both Cribb (1991) and Sadr (1991) have developed strategies for this, utilizing intensive regional surveys to locate the various interacting mobile and sedentary components in the archaeological landscape, and carefully considering artifact densities and depth of deposits. An excellent starting point would be a systematic examination of the flat, more ephemeral surface sites in the MSV, and an extension of the area investigated to the area south of the floodplain, where 
pastoral transhumance routes were located historically. Recovery of larger faunal samples through more extensive excavation should provide data on cattle diversity (assessed by the size categories present-MacDonald \& MacDonald 2000) and herd structure (differential off-take patterns) at different sites.

Thus far, we have focused on the historical development of the distinctive, traditional Fulbe pastoral system within the geographical area of the northern Atlantic languages. However, another part of our inquiry concerns the distinctive genetic profile of the Fulbe. Therefore, the final section of this paper will consider ways to investigate the context and chronology of these elements, namely, the distinctive AAC clusters noted by Tishkoff et al. (2009; documented primarily for sampled Fulbe populations further to the east), the European lactase persistence allele and haplotype, and the low frequencies of mtDNA and NRY lineages of North African, Mediterranean, or Near Eastern origin. Lactase persistence is particularly interesting.

African pastoralist populations appear to have a variety of alleles that allow them to continue producing into adulthood the intestinal enzyme lactase that is responsible for the digestion of the milk sugar, lactose (Ingram et al. 2007; Tishkoff et al. 2007). For most of the world's population, lactase production declines after weaning, and they cannot digest milk without experiencing some degree of intestinal distress, unless the milk sugar has been broken down by bacteria through culturing or fermentation prior to consumption (Ingram et al. 2009). The lactase persistence trait makes the drinking of raw milk possible, and this is thought to have conferred a definite selective advantage for African pastoralists in hot, arid conditions where food and clean, uncontaminated water or other fluids are scarce (Ingram et al. 2009:588). Four SNPs located approximately 14,000 bases upstream of the lactase gene have been demonstrated to significantly affect the regulation of lactase production, suggesting a causative role in the mechanism of lactase persistence (Tishkoff et al. 2007). Two of these appear to have originated in East Africa, one in the Arabian peninsula where it is associated with camel pastoralism and the drinking of camel milk, and one in Europe (Enattah et al. 2008; Tishkoff et al. 2007; Fig. 15). The 13910*T allele is found at very high frequencies in Europe in a genomic region of reduced diversity and extended linkage disequilibrium (regions where recombination has not yet shuffled the area of DNA surrounding the allele), which suggests relatively recent, strong positive selection (Itan et al. 2010). It is also the predominant LP allele in the Fulbe populations tested (Mali-Lokki et al. 2011; Cameroon-Ingram et al. 2009; Fig. 16). How did this allele with an otherwise European/Eurasian distribution end up in Fulbe genomes?

One possibility is that it was acquired through relatively recent interactions $(\leq 2,000$ ya) with Berber and/or Arab populations, who also carry this allele. With additional genetic data from northern and northeastern African populations, especially Fulbe and neighboring populations from Mauritania and Senegal, we could use the patterns of variation in microsatellite markers (Coelho et al. 2005) and linkage disequilibrium in the region surrounding the $-13910^{*} \mathrm{~T}$ allele to test whether contemporary Berber and Arab populations have higher levels of microsatellite variation and smaller regions of linkage disequilibrium relative to the Fulbe. If they do, it would indicate that they have carried the $13910^{*} \mathrm{~T}$ allele longer than the Fulbe have and could have been the source. 
Chr 2
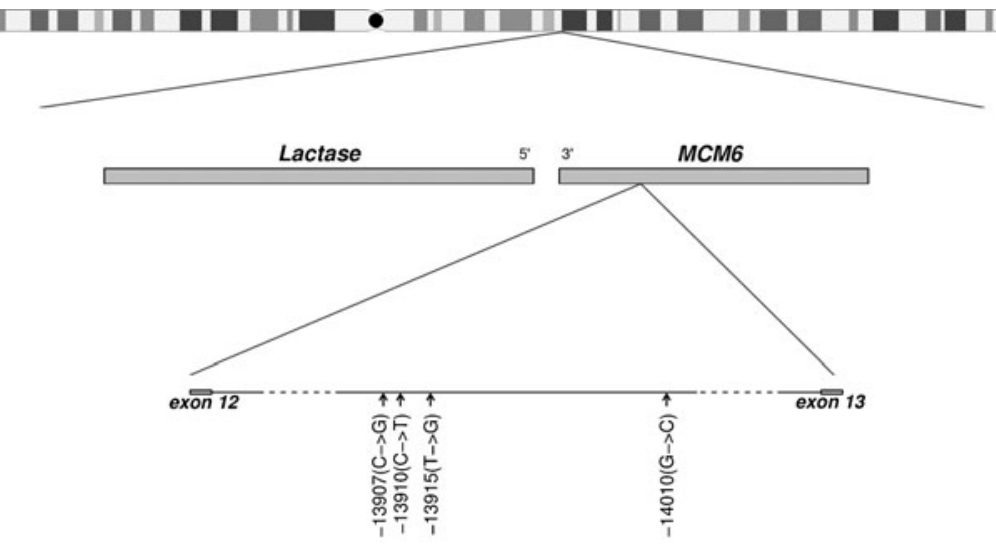

$-13907 \mathrm{G}$ - East Africa

-13910T - Europe

$-13915 G$ - Middle East

$-14010 \mathrm{C}$ - East Africa

Fig. 15 Lactase gene variants. Lactase (LCT) and MCM6 are two genes located side by side on chromosome 2. The four SNPs that have been shown to impact the gene expression of LCT are located between the 12th and 13th exons (coding regions) of MCM6. These SNPs are labeled and the geographic regions where the persistence allele is thought to have arisen are listed. Dashed lines indicate larger distances between the SNP and exon locations within MCM6 (data reviewed in Ingram et al. 2009)

Alternatively, populations ancestral to the Fulbe could have acquired the $-13910 * \mathrm{~T}$ allele much earlier while in north central or northeast Africa (possible source areas for those "distinctive" AAC's). Both of these areas are early centers of cattle pastoralism from at least 6000 BCE. In the Central Saharan massifs of the Tadrart Acacus, Tassili, Ennedi, Hoggar, and Aïr, rock art testifies to a flourishing pastoral era, first dominated by cattle and later dominated by ovicaprids. The recent identification of dairy fat residues in pottery from a Pastoralist Period rock shelter site in southwest Libya places the beginnings of milking at around $5000 \mathrm{BCE}$, since dairy fats were not detected in pottery from earlier hunting/gathering and Pastoralist phases at the site (Dunne et al. 2012).

With increasing aridity, groups of cattle herders are well documented between 4000 and $2500 \mathrm{cal} \mathrm{BCE}$ to the south and west, in the Teneré (Gifford-Gonzalez 2008), the Azawagh Valley of Niger (Paris 1996, 2000), and the Tilemsi Valley in Mali (Smith 1979; Manning 2011). Some or all were presumably using milk. Between 2500 and 2000 BCE, millet was domesticated, and agropastoral economies spread widely in the Sahel from 2000 cal BCE, although there is definite evidence for pastoral economies without millet continuing in some areas (Breunig \& Neumann 2002). It appears that cattle-herders (with or without millet) arrived in the dhar region of Mauritania at about this time. Did they milk? And if so, what LP allele(s) did they carry?

The fact that all North Atlantic speakers (Fulbe, Wolof, and Serer) have high frequencies (50-100\%-Itan 2010) of lactase persistence (Fig. 17) suggests a considerable history of dairying in the region. Of these, only the Wolof have been genotyped for lactase persistence alleles, and, intriguingly, they carry none of the four alleles identified to date (Global Lactase Persistence Database: http://www.ucl.ac.uk/ 


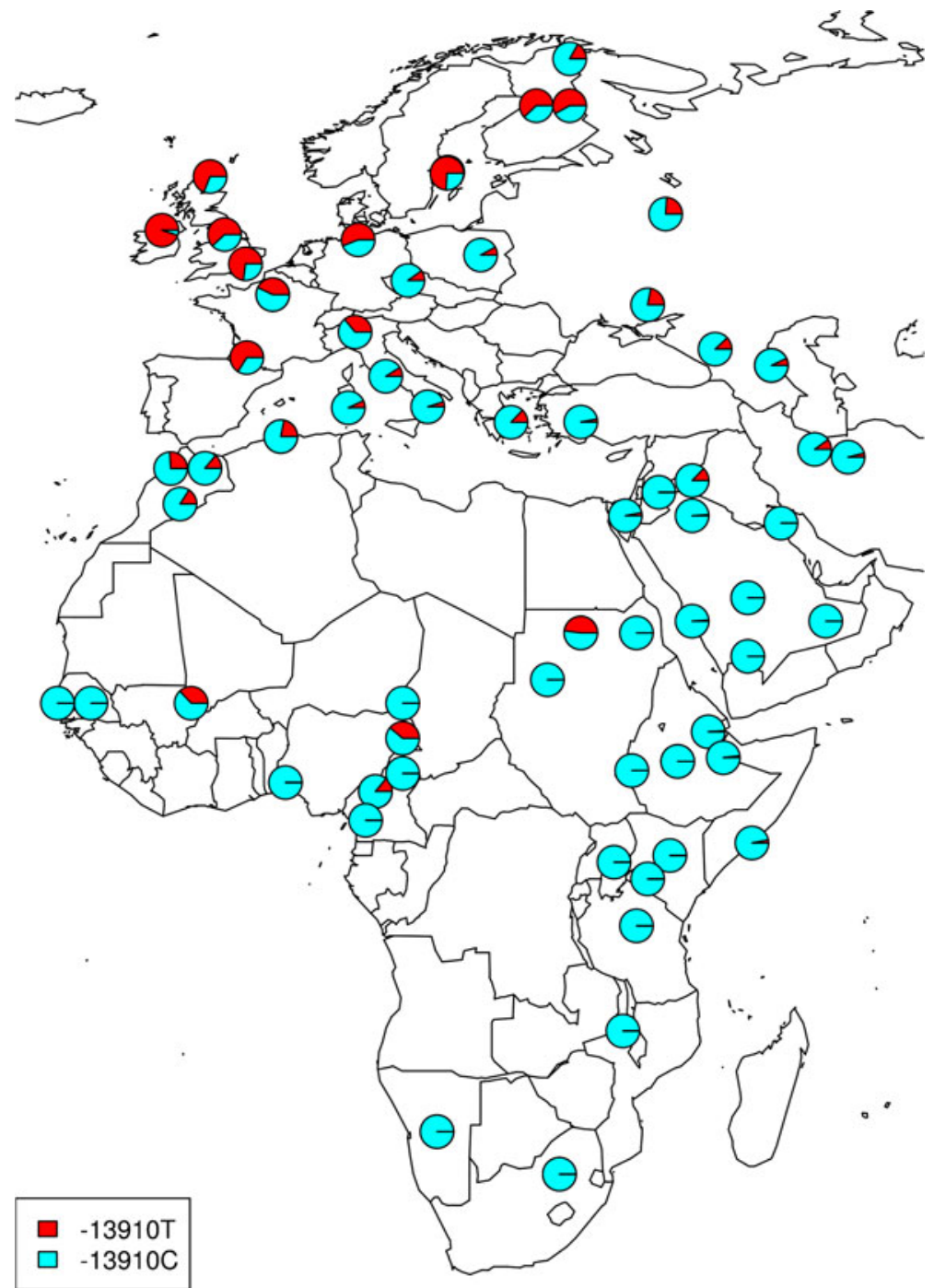

Fig. 16 Frequency of the $-13910 \mathrm{~T}$ lactase persistence allele in Africa and Eurasia (data reviewed in Ingram et al. 2009 and supplemented with data from Lokki et al. 2011)

mace-lab/resources/glad). This suggests that we still have much to discover about the history and convergent evolution of lactase persistence in Africa. This point is reinforced by the fact that the four known alleles do not explain the full extent to which lactase persistence is present in many African populations (e.g., Tishkoff et al. 2007). Therefore, the identification and genotyping of these alleles in Western and Central Africa with corresponding microsatellite and linkage disequilibrium data would provide additional information regarding the spread of dairying peoples in general and past movements of populations ancestral to North Atlantic speakers in particular. 


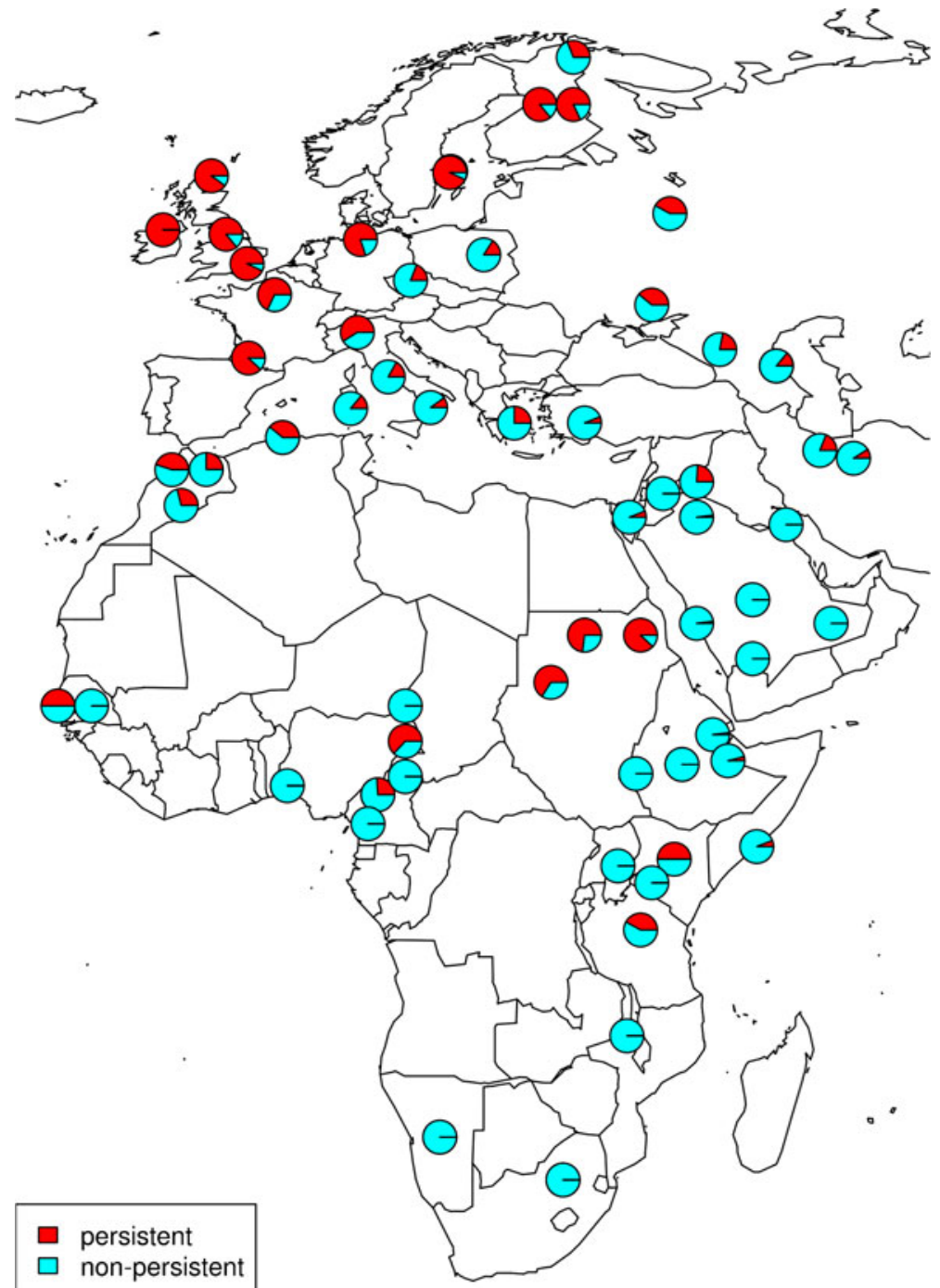

Fig. 17 Frequency of lactase persistence in Africa and Eurasia (data reviewed in Ingram et al. 2009)

However fine the resolution that may be achieved regarding modern genetic variation, direct evidence for past population variability and its geographic distribution remains a yawning gap. For the questions we are interested in-e.g., the distributions and interactions of various North African, Eurasian and sub-Saharan populations at various points during the Holocene, the distribution of genetic variation with regard to different hunting/collecting/fishing and pastoral groups that lived in the Sahara during the Holocene- the study of ancient DNA offers a potential route to relevant data. Although human skeletal remains are abundant in the Sahara and Sahel, the unfortunate fact is that DNA is a fragile molecule that degrades in relation to temperature and other factors, with preservation predicted to be lowest in hot, 
humid climates (Brown \& Brown 2011; Ottoni 2008). Attempts to extract ancient DNA from cattle bones from two archaeological sites in the Sahelian zone of Senegal and Mali had a $25 \%$ success rate (Edwards et al. 2004). Of over a dozen human remains analyzed from Libyan pastoralist sites, only one yielded mtDNA that could be characterized as to haplogroup (Babalini et al. 2002; Ottoni 2008). However, the apparent success in retrieving ancient DNA from 34 of 50 burials in a Roman cemetery in Dakhleh Oasis (Graver et al. 2001) and from a dozen 12,000-year-old skeletons from Taforalt cave in Morocco (Kefi et al. 2005) provides a reason for cautious hope. Unfortunately, the many human remains previously collected by Saharan and Sahelian expeditions are unlikely to be suitable candidates, as scrupulous collection and processing protocols must be followed to avoid contamination with modern DNA. Future research projects that recover human remains should do so under the conditions that would make testing for ancient DNA feasible.

As a final research methodology that is useful for investigating population differences that may signal the arrival of immigrant groups or the mixing of phenotypically distinctive groups, bioarchaeology must be mentioned. Human skeletal material has been one of the most underutilized sources of information about the West African past. Many archaeological sites in the Sahel and Sahara have burials that have been exposed by erosion or deflation. Hundreds have been excavated in the last three decades, but most have been studied only briefly to estimate sex and age at death (Dutour 1989 and Petit-Maire 1979 are notable exceptions). This overlooks the potential of this material for biodistance or biological affinity analysis with other populations. Measurements on the neurocranium and the facial skeleton have long been used to assess the degree of biological relatedness among living and past populations. While the human bones from West African sites are often too fragmentary for metric studies, teeth are usually better preserved, and the study of dental nonmetric traits (Scott and Turner 1997) can provide evidence on population affinities and changes in the biological composition of groups due to migration (e.g., Irish 1998, 2000, 2005). Development of a database of dental non-metrics for the many excavated remains from throughout West Africa and the Sahara should be a priority, a project that C. Stojanowski (personal communication) has already initiated. Teeth can often be analyzed for the incidence of caries and indicators of childhood stress and disease, such as enamel hypoplasias, even when bones are too degraded for identification of other hard tissue pathologies. Isotopic analysis of teeth is another powerful analytical tool. Particularly for studies of pastoralism, microsampling of growth increments of tooth enamel, and analysis of various isotopes such as strontium, lead, and oxygen can reveal seasonal mobility as well as migration (Balasse et al. 2002; Brown \& Brown 2011, pp. 85-87; Smith 2012).

\section{Conclusion}

Genetic analysis and archaeology have partnered productively in investigating the early expansion of Austronesian speakers from Southeast Asia into Near Oceania and western Polynesia. Several factors have made it possible for archaeological and genetic studies to converge at comparable levels of chronological and temporal resolution. On the genetics side, these include: 
- A steady increase over the past decade in numbers of Oceanic and Southeast Asian populations sampled for genetic analysis

- Increased use of genome-wide analysis accompanied by improvements in demographic modeling and computational methods to infer finer-grained population structure in Melanesian and Polynesian population samples

- Enhanced precision in dating the emergence of the "Polynesian motif" in Melanesia using whole mtDNA sequence data (Soares et al. 2011).

On the archaeological side, there is the requisite critical mass of local, regional, and extra-regional site documentation, including:

- Well-described and dated archaeological sequences on a wide variety of the islands of Near and Remote Oceania

- Precise dates for the Lapita horizon, identified at some 200 sites

- Documentation for pre-Lapita assemblages in Near Oceania and Island Southeast Asia and late and post-Lapita assemblages more widely (Spriggs 2011).

The outcome of this convergence is the recognition that the early Austronesian expansion did not emanate from a single source (Taiwan or Melanesia) and transmit a Neolithic "package" of new plants, animals, artifacts types, and technologies. The process was more complex, involving gene flow from multiple areas and local cultural patterns of hybridity and innovation (Spriggs 2011; Green 1991). Better sampling and improved methods in both archaeology and genetics have thus enabled the consideration of social process at the mesoscale level of the conjoncture. Our Pacific case study demonstrates that the oft-lamented incommensurability of the temporal and spatial frameworks employed for archaeological and genetic data can be surmounted.

The research conditions that enable this desirable convergence are lacking in our West African example, however. Available genetic data are of limited utility because the North Atlantic language populations of greatest interest-Wolof, Serer, Tukolor, and Senegalese Fulbe - along with neighboring groups in southern Mauritania and eastern Senegal/Western Mali, are all among the most poorly sampled in West Africa. One sure path to higher resolution inferences on population structure is assembling "dense sample sets of known and detailed provenance" within a historically informed research program (Veeramah et al. 2010). Increased use of genome-wide genetic analysis is another. In addition, we have outlined a particular focus on studies of the lactase gene and microsatellites in its surrounding region as a possible method for inferring the antiquity of interactions of dairying groups and non-dairying groups in different areas. Historical linguistic analysis of Fulfulde and other North Atlantic languages might reveal loan words for herding and/or milking that help reconstruct interactions that introduced new cultural practices. To date, this has not been investigated (R. Blench, personal communication).

An even more pressing need is the establishment of a basic archaeological database for the regions mentioned above, comprising well-dated information from closed excavation contexts on material culture, subsistence economy, exotics, technology, and settlement layout. Currently, this is available for certain chronological periods since 2500 BP in only a handful of areas along the Senegal 
River (Delta: Mbow 1997; Middle Valley: Bocoum 2000; Chavane 1985; Deme 2003; Deme \& McIntosh 2006; McIntosh \& Bocoum 2000; McIntosh et al. 2012; Upper Senegal: Gokee 2012; Thiaw 1999), and is rare to nonexistent elsewhere in Senegal and in much of southernmost Mauritania. Further afield, the larger picture of pastoralism's spread is still painted with very broad strokes for much of West Africa; we need many more projects designed to illuminate the chronology, local context, and development of economies with herding components (e.g., Breunig and Neumann 2002; Garcea 2012; Gifford-Gonzalez 2008; MacDonald 1994; Manning 2008). In addition, incorporating a well-designed bioarchaeology focus into research projects will help clarify to what extent the spread of pastoralism involved the migration of pastoralists (demic expansion) or the adoption of livestock and herding practices by local hunting/collecting groups. In the case of the Fulbe, biometric data and dental non-metric data can be used to investigate affinities with archaeological populations and to study the emergence of a distinctive Fulbe morphology, providing a complementary dataset to that provided by genetic analysis. Using this kind of multidisciplinary approach, we can move beyond the macroscale interpretations that have largely characterized efforts to integrate African genetic, archaeological, and linguistic data to date and better focus on the economic and climatic factors, the regional and local interactions, and social dynamics implicated in culture change and ethnogenesis.

AcknowledgmentsWe are grateful to Roger Blench and Scott MacEachern for reading a draft of this paper and making useful suggestions. In addition, we thank Jonathan S. Friedlaender, Françoise Friedlaender, and Janet Monge for helpful discussions.

\section{References}

Abu-Manga, A.-A. (1999). Socio-cultural, socio-economic and socio-linguistic diversity among the Fulbe of the Sudan Republic. In V. Azarya, A. Breedveld, M. de Bruijn, \& H. Van Dijk (Eds.), Pastoralists under pressure?: Fulbe societies confronting change in West Africa (pp. 51-68). Leiden: Brill.

Amblard-Pison, S. (2006). Communautes villageoises neolithiques des Dhars Tichitt et Oualata (Mauritanie). Oxford: British Archaeological Reports.

Anfinset, N. (2010). Metal, nomads and culture contact: The Middle East and North Africa (Approaches to anthropological archaeology). London: Equinox.

Babalini, C., Martinez-Labarga, C., Lorente, J. A., Lorente, M., \& Rickards, O. (2002). Ancient DNA studies: First results. In S. di Lernia \& G. Manzi (Eds.), Sand, stones, and bones: The archaeology of death in the Wadi Tanezzuft Valley (5000-2000 BP) (pp. 269-280). Firenze: All'Insegna del Giglio.

Balasse, M., Ambrose, S., Smith, A. B., \& Price, T. D. (2002). The seasonal mobility model for prehistoric herders in the South-western Cape of South Africa assessed by isotopic analysis of sheep tooth enamel. Journal of Archaeological Science, 29, 917-932.

Barbieri, C., Whitten, M., Beyer, K., Schreiber, H., Li, M., \& Pakendorf, B. (2012). Contrasting maternal and paternal histories in the linguistic context of Burkina Faso. Molecular Biology and Evolution, 29 (4), 1213-1223.

Barth, F. (1969). Ethnic groups and boundaries: The social organization of culture difference. London: Little, Brown.

Bathily, M., Khattar, M., \& Vernet, R. (1998). Les sites néolithiques de Khat Lemaïteg (Amatlich) en Mauritanie occidentale. Nouakchott: C.R.I.A.

Beleza, S., Gusmao, L., Amorim, A., Carracedo, A., \& Salas, A. (2005). The genetic legacy of western Bantu migrations. Human Genetics, 117(4), 366-375. 
Blanc, M., Sanchez-Mazas, A., Van Blyenburgh, N. H., Sevin, A., Pison, G., \& Langaney, A. (1990). Interethnic genetic differentiation: GM polymorphism in eastern Senegal. The American Journal of Human Genetics, 46(2), 383-383.

Blench, R. (1999). Why are there so many pastoral groups in eastern Africa? In V. Azarya, A. Breedveld, M. de Bruijn, \& H. Van Dijk (Eds.), Pastoralists under pressure?: Fulbe societies confronting change in West Africa (pp. 29-50). Leiden: Brill.

Blench, R. M. (1990). FulBe, Fulani and Fulfulde in Nigeria: Distribution and identity. Abuja: NLC Working paper series

Bocoum, H. (2000). L'Age du fer au Sénégal: Histoire et archéologie. Dakar: IFAN and Nouakchatt: CRIAA.

Boutrais, J. (1994). Pour une nouvelle cartographie des Peuls. Cahiers d'études africaines, XXXIV(133135), 137-146.

Brasseur, P., \& Brasseur, G. (1981). Le Peul imaginaire. In Le sol, la parole, et l'écrit, Vol. I (pp. 471-478). Paris: Société française d'histoire d'outre-mer.

Braukamper, U. (1993). Notes on the origin of the Baggara Arab culture with special reference to the Shuwa. Sprache und Geschichte in Afrika, 14, 13-46.

Breunig, P., \& Neumann, K. (2002). From hunters and gatherers to food producers: New archaeological and archaeobotanical evidence from the West African Sahel. In F. A. Hassan (Ed.), Droughts, food and culture (pp. 123-155). Boston: Kluwer Academic.

Brown, K., \& Pluciennik, M. (2001). Archaeology and human genetics: Lessons for both. Antiquity, 75, 101-106.

Brown, T., \& Brown, K. (2011). Biomolecular archaeology: An introduction. Oxford: Wiley-Blackwell.

Cann, R. L., Stoneking, M., \& Wilson, A. C. (1987). Mitochondrial DNA and human evolution. Nature, 325(6099), 31-36.

Capelli, C., Wilson, J. F., Richards, M., Stumpf, M. P., Gratrix, F., Oppenheimer, S., Goldstein, D. B., et al. (2001). A predominantly indigenous paternal heritage for the Austronesian-speaking peoples of insular Southeast Asia and Oceania. The American Journal of Human Genetics, 68(2), 432-443. doi:10.1086/ 318205.

Cavalli-Sforza, L. L., Menozzi, P., \& Piazza, A. (1994). The history and geography of human genes. Princeton: Princeton University Press.

Cerezo, M., Cerny, V., Carracedo, A., \& Salas, A. (2011). New insights into the Lake Chad Basin population structure revealed by high-throughput genotyping of mitochondrial DNA coding SNPs. PloS One, 6(4), e18682-e18682.

Cerny, V., Hajek, M., Bromova, M., Cmejla, R., Diallo, I., \& Brdicka, R. (2006). mtDNA of Fulani nomads and their genetic relationships to neighboring sedentary populations. Human Biology, 78(1), 9-27.

Cerny, V., Pereira, L., Musilova, E., Kujanova, M., Vasikova, A., Blasi, P., \& Novelletto, A. (2011). Genetic structure of pastoral and farmer populations in the African Sahel. Molecular Biology and Evolution, 28 (9), 2491-2500.

Chappell, J., Omura, A., McCullock, M., Esat, M., Ota, Y., \& Pandolfi, J. (1994). Revised late Quaternary sea levels between 70 and $30 \mathrm{ka}$ from coral terraces at Huon Peninsula. In Study on coral reef terraces of the Huon Peninsula, Papua New Guinea: Establishment of Quaternary sea level and tectonic history (pp. 155-165). Yokohama: Yokohama National University.

Chavane, B. (1985). Villages de l'ancien Tekrour. Paris: Editions Karthala.

Coelho, M., Luiselli, D., Bertorelle, G., Lopes, A. I., Seixas, S., Destro-Bisol, G., \& Rocha, J. (2005). Microsatellite variation and evolution of human lactase persistence. Human Genetics, 117(4), 329-339.

Coia, V., Brisighelli, F., Donati, F., Pascali, V., Boschi, I., Luiselli, D., Destro-Bisol, G., et al. (2009). A multi-perspective view of genetic variation in Cameroon. American Journal of Physical Anthropology, $140(3), 454-464$.

Cox, M., \& Layr, M. (2006). Y-chromosome diversity is inversely associated with language affiliation in paired Austronesian- and Papuan-speaking communities from Solomon Islands. American Journal of Human Biology, 18(1), 35-50.

Cribb, R. (1991). Nomads in archaeology. Cambridge: Cambridge University Press.

Cruciani, F., Santolamazza, P., Shen, P., Macaulay, V., Moral, P., Olckers, A., Underhill, P. A., et al. (2002). A back migration from Asia to sub-Saharan Africa is supported by high-resolution analysis of human Y-chromosome haplotypes. The American Journal of Human Genetics, 70(5), 1197-1214.

Cruciani, F., Trombetta, B., Sellitto, D., Massaia, A., Destro-Bisol, G., Watson, E., Scozzari, R., et al. (2010). Human Y chromosome haplogroup R-V88: A paternal genetic record of early mid Holocene trans-Saharan connections and the spread of Chadic languages. European Journal of Human Genetics, 18(7), 800-807. 
David, N. (1971). The Fulani compound and the archaeologist. World Archaeology, 3(2), 111-131.

Deme, A. (2003). Archaeological investigation of settlement evolution and emerging complexity in the Middle Senegal Valley. PhD dissertation, Rice University.

Deme, A., \& McIntosh, S. K. (2006). Excavations at Walaldé: New light on the settlement of the Middle Senegal Valley by iron-using peoples. Journal of African Archaeology, 4(2), 317-347.

Diamond, J. M. (1988). Express train to Polynesia. Nature, 336(6197), 307-308. doi:10.1038/336307a0.

Dieterlen, G., \& Ba, A. H. (1966). Les fresques d'époque bovidienne du Tassili N'Ajjer et les traditions des Peul: Hypothèses d'interprétation. Journal de la Société des Africanistes, 36(1), 141-157.

Diop, C. A. (1959). The cultural unity of Black Africa. Chicago: Third World Press.

Dunn, M., Terrill, A., Reesink, G., Foley, R. A., \& Levinson, S. C. (2005). Structural phylogenetics and the reconstruction of ancient language history. Science, 309(5743), 2072-2075.

Dunne, J., Evershed, R. P., Salque, M., Cramp, L., Bruni, S., Ryan, K., Lernia, S. D., et al. (2012). First dairying in green Saharan Africa in the fifth millennium bc. Nature, 486(7403), 390-394.

Dupire, M. (1962). Peuls nomades, Etude descriptive des Wodaabe du Sahel Nigérien. Paris: Institut d'Ethnologie (Mâcon: Impr. Protat Frères).

Dupire, M. (1994). Identité ethnique et processus d'incorporation tribal et étatique. Cahiers d'études africaines, $X X X I V(133-135), 265-280$.

Dutour, O. (1989). Hommes fossiles du Sahara: Peuplements holocénes du Mali septentrional. Paris: Editions du Centre National de la Recherche Scientifique.

Edwards, C. J., MacHugh, D. E., Dobney, K. M., Martin, L., Russell, N., Horwitz, L. K., Bradley, D. G., et al. (2004). Ancient DNA analysis of 101 cattle remains: Limits and prospects. Journal of Archaeological Science, 31(6), 695-710.

Enattah, N. S., Jensen, T. G. K., Nielsen, M., Lewinski, R., Kuokkanen, M., Rasinpera, H., Peltonen, L., et al. (2008). Independent introduction of two lactase-persistence alleles into human populations reflects different history of adaptation to milk culture. The American Journal of Human Genetics, 82(1), 57-72.

Excoffier, L., Pellegrini, B., Sanchez-Mazas, A., Simon, C., \& Langaney, A. (1987). Genetics and history of sub-Saharan Africa. American Journal of Physical Anthropology, 30(S8), 151-194.

Foley, W. A. (1986). The Papuan language of New Guinea. Cambridge: Cambridge University Press.

Friedlaender, J., Schurr, T., Gentz, F., Koki, G., Friedlaender, F. R., Horvat, G., Merriwether, D. A., et al. (2005). Expanding Southwest Pacific mitochondrial haplogroups P and Q. Molecular Biology and Evolution, 22(6), 1506-1517. doi:10.1093/molbev/msi142.

Friedlaender, J. S., Friedlaender, F. R., Hodgson, J. A., Stoltz, M., Koki, G., Horvat, G., Merriwether, D. A., et al. (2007). Melanesian mtDNA complexity. PloS One, 2(2), e248-e248. doi:10.1371/ journal.pone.0000248.

Friedlaender, J. S., Friedlaender, F. R., Reed, F. A., Kidd, K. K., Kidd, J. R., Chambers, G. K., Weber, J. L., et al. (2008). The genetic structure of Pacific Islanders. PLoS Genetics, 4(1), e19-e19. doi:10.1371/ journal.pgen.0040019.

Garcea, E. (2012). Gobero: The no-return frontier: Archaeology and landscape at the Saharo-Sahelian borderland. Frankfurt: Afrika Magna Verlag.

Garrigan, D., Kingan, S. B., Pilkington, M. M., Wilder, J. A., Cox, M. P., Soodyall, H., Hammer, M. F., et al. (2007). Inferring human population sizes, divergence times and rates of gene flow from mitochondrial, $\mathrm{X}$ and $\mathrm{Y}$ chromosome resequencing data. [Research Support, N.I.H., Extramural]. Genetics, 177 (4), 2195-2207. doi:10.1534/genetics.107.077495.

Gifford-Gonzalez, D. P. (2008). Adrar Bous: Archaeology of a central Saharan granitic ring complex in Niger. Tervuren: Royal Museum for Central Africa.

Gokee, C. (2012). Daily life in the land of Bambuk: An archaeological study of political economy at Diouboye, Senegal. PhD dissertation, University of Michigan, Ann Arbor, Michigan.

Gonzalez, A. M., Cabrera, V. M., Larruga, J. M., Tounkara, A., Noumsi, G., Thomas, B. N., \& Moulds, J. M. (2006). Mitochondrial DNA variation in Mauritania and Mali and their genetic relationship to other Western Africa populations. Annals of Human Genetics, 70(5), 631-657.

Graver, A., Molto, E., Parr, R., Praymak, R., Walters, S., \& Maki, J. (2001). Mitochondrial DNA research in the Dakhleh Oasis, Egypt: A preliminary report. Ancient Biomolecules, 3, 239-253.

Green, R. (1991). The Lapita cultural complex: Current evidence and proposed models. Bulletin of the Indo-Pacific Prehistory Association, 11, 295-305.

Greenberg, J. (1949). Studies in African linguistic classification: II. The classification of Fulani. Southwestern Journal of Anthropology, 5(3), 190-198.

Greenberg, J. (1963). The languages of Africa. Bloomington: Indiana University Press.

Groube, L., Chappell, J., Muke, J., \& Price, D. (1986). A 40,000 year-old human occupation site at Huon Peninsula, Papua New Guinea. Nature, 324(6096), 453-455. doi:10.1038/324453a0. 
Gueye, N. S. (1998). Poteries et peuplements de la Moyen Vallée du Fleuve Sénégal du XVIe au XXe siècles: Approaches ethnoarchéologique et ethnohistorique. Thèse de doctorat, Nanterre: Université de Paris X.

Hassan, H. Y., Underhill, P. A., Cavalli-Sforza, L. L., \& Ibrahim, M. E. (2008). Y-chromosome variation among Sudanese: Restricted gene flow, concordance with language, geography, and history. American Journal of Physical Anthropology, 137(3), 316-323.

Henn, B. M., Botigué, L. R., Gravel, S., Wang, W., Brisbin, A., Byrnes, J. K., Comas, D., et al. (2012). Genomic ancestry of North Africans supports Back-to-Africa migrations. PLoS Genetics, 8(1), e1002397-e1002397.

Hertzberg, M., Mickleson, K. N., Serjeantson, S. W., Prior, J. F., \& Trent, R. J. (1989). An Asian-specific 9bp deletion of mitochondrial DNA is frequently found in Polynesians. The American Journal of Human Genetics, 44(4), 504-510.

Hiernaux, J. (1975). People of Africa. New York: Charles Scribner's Sons.

Ingram, C. J. E., Elamin, M. F., Mulcare, C. A., Weale, M. E., Tarekegn, A., Raga, T. O., Swallow, D. M., et al. (2007). A novel polymorphism associated with lactose tolerance in Africa: Multiple causes for lactase persistence? Human Genetics, 120(6), 779-788.

Ingram, C. J. E., Mulcare, C. A., Itan, Y., Thomas, M. G., \& Swallow, D. M. (2009). Lactose digestion and the evolutionary genetics of lactase persistence. Human Genetics, 124(6), 579-591.

Irish, J. (1998). Dental morphological affinities of Late Pleistocene through recent sub-Saharan and North African peoples. Bulletins et Memoires de la Societé d'Anthropologie de Paris, nouvelle serie, 10, 237-272.

Irish, J. (2000). The Iberomaurusian enigma: North African progenitor or dead end? Journal of Human Evolution, 39(4), 393-410.

Irish, J. (2005). Population continuity versus discontinuity revisited: Dental affinities among Late Paleolithic through Christian-era Nubians. American Journal of Physical Anthropology, 128, 520-535.

Itan, Y., Jones, B. L., Ingram, C. J. E., Swallow, D. M., \& Thomas, M. G. (2010). A worldwide correlation of lactase persistence phenotype and genotypes. BMC Evolutionary Biology, 10(1), 36-36.

Jodin, A. (1966). Bijoux et amulettes du Maroc Punique. Bulletin d'Archéologie Marocaine, 6, 55-90.

Kéfi, R., Stevanovitch, A., Bouzaid, E., \& Béraud-Colomb, E. (2005). Diversité mitochondriale de la population de Taforalt (12.000 ans BP - Maroc): Une approche génétique a l'étude du peuplement de l'Afrique du nord. Anthropologie. International Journal of the Science of Man, 43(1), 1-11.

Karafet, T. M., Mendez, F. L., Meilerman, M. B., Underhill, P. A., Zegura, S. L., \& Hammer, M. F. (2008). New binary polymorphisms reshape and increase resolution of the human Y chromosomal haplogroup tree. Genome Research, 18(5), 830-838.

Karafet, T. M., Osipova, L. P., Gubina, M. A., Posukh, O. L., Zegura, S. L., \& Hammer, M. F. (2002). High levels of Y-chromosome differentiation among native Siberian populations and the genetic signature of a boreal hunter-gatherer way of life. Human Biology, 74(6), 761-789.

Kayser, M., Brauer, S., Weiss, G., Schiefenhövel, W., Underhill, P., Shen, P., Stoneking, M., et al. (2003). Reduced Y-chromosome, but not mitochondrial DNA, diversity in human populations from West New Guinea. The American Journal of Human Genetics, 72(2), 281-302. doi:10.1086/346065.

Kayser, M., Lao, O., Saar, K., Brauer, S., Wang, X., Nürnberg, P., Stoneking, M., et al. (2008). Genomewide analysis indicates more Asian than Melanesian ancestry of Polynesians. The American Journal of Human Genetics, 82(1), 194-198. doi:10.1016/j.ajhg.2007.09.010.

Keita, S. O. Y. (2005). Physical anthropology and African history. In J. E. Philips (Ed.), Writing African history. Rochester: University of Rochester Press.

Keita, S. O. Y., Jackson, F. L. C., Borgelin, L. F. J., \& Maglo, K. N. (2010). Letter to the editor: Commentary on the Fulani-History, genetics, and linguistics, an adjunct to Hassan et al., 2008. American Journal of Physical Anthropology, 141(4), 665-667.

Kimura, R., Ohashi, J., Matsumura, Y., Nakazawa, M., Inaoka, T., Ohtsuka, R., Tokunaga, K., et al. (2008). Gene flow and natural selection in oceanic human populations inferred from genome-wide SNP typing. [Comparative Study Research Support, Non-U.S. Gov't]. Molecular Biology and Evolution, 25(8), 1750-1761. doi:10.1093/molbev/msn128.

Kirch, P. V. (1991). Prehistoric exchange in Western Melanesia. Annual Review of Anthropology, 20(1), 141-165. doi:10.1146/annurev.an.20.100191.001041.

Kirch, P. V. (1997). The Lapita peoples: Ancestors of the Oceanic world. Malden: Blackwell.

Kirch, P. V. (2002). On the road of the winds: An archaeological history of the Pacific Islands before European contact. Berkeley: University of California Press.

Kivisild, T., Shen, P., Wall, D. P., Do, B., Sung, R., Davis, K., Oefner, P. J., et al. (2006). The role of selection in the evolution of human mitochondrial genomes. Genetics, 172(1), 373-387. 
Kyburz, O. (1994). Les hierarchies socials et leurs fondements idéologiques chez les hal-pulaar'en (Senegal). Thèse de doctorat, Université de Parix X- UMR116.

Lam, A. M. (2003). De l'origine Egyptienne des Peuls. Montreal: Editions Hurtubise HML Ltee.

Leavesley, M. G., Bird, M. I., Fifield, L. K., Hausladen, P. A., Santos, G. M., \& di Tada, M. L. (2002). Buang Merabak: Early evidence for human occupation in the Bismarck Archipelago, Papua New Guinea. Australian Archaeology, 54, 55-57.

Lokki, A. I., Järvelä, I., Israelsson, E., Maiga, B., Troye-Blomberg, M., Dolo, A., et al. (2011). Lactase persistence genotypes and malaria susceptibility in Fulani of Mali. Malaria Journal, 10(1), 9-9.

MacDonald, K. (1999). Invisible pastoralists: An inquiry into the origins of nomadic pastoralism in the West African Sahel. In C. Gosden \& J. Hather (Eds.) The prehistory of food: Appetites for change. (pp. 326-341): New York: Psychology Press.

MacDonald, K., \& MacDonald, R. H. (2000). The origins and development of domesticated animals in arid West Africa. In R. M. Blench \& K. C. MacDonald (Eds.), The origins and development of African livestock (pp. 127-162). London: UCL Press.

MacDonald, K. C. (1994). Socio-economic diversity and the origins of cultural complexity along the Middle Niger (2000 BC to AD 300). Cambridge: University of Cambridge. Ph.D. dissertation.

MacDonald, K. C., Vernet, R., Martinon-Torres, M., \& Fuller, D. Q. (2009). Dhar Néma: From early agriculture to metallurgy in southeastern Mauritania. Azania: Archaeological Research in Africa, 44(1), 3-48.

MacEachern, S. (2000). Genes, tribes, and African history. Current Anthropology, 41(3), 357-384.

Malhi, R. S., Breece, K. E., Shook, B. A. S., Kaestle, F. A., Chatters, J. C., Hackenberger, S., \& Smith, D. G. (2004). Patterns of mtDNA diversity in northwestern North America. Human Biology, 76(1), 33-54.

Manni, F., Leonardi, P., Barakat, A., Rouba, H., Heyer, E., Klintschar, M., Quintana-Murci, L. S., et al. (2002). Y-chromosome analysis in Egypt suggests a genetic regional continuity in Northeastern Africa. Human Biology, 74(5), 645-658.

Manning, K. (2008). Mobility, climate change and cultural development: A revised view from the Lower Tilemsi Valley, Northeastern Mali. Oxford: University of Oxford. Ph.D. dissertation.

Manning, K. (2011). The first herders of the West African Sahel. In H. Jousse \& J. Lesur (Eds.), People and animals in Holocene Africa. Frankfurt: Africa Magna Verlag.

Mbow, M. A. (1997). Les amas coquilliers du delta du Sénégal: Etude ethno-archéologique. Thèse de doctorat, Université de Paris I, Pantheon-Sorbonne.

McIntosh, R. J. (1993). The Pulse Model: Genesis and accommodation of specialization in the Middle Niger. The Journal of African History, 34(2), 181-220.

McIntosh, R. J., McIntosh, S. K., \& Bocoum, H. (2012). Seeking the origins of Takrur: Excavations and survey in the Middle Senegal Valley. New Haven: Yale University Publications in Anthropology.

McIntosh, S. K., \& Bocoum, H. (2000). New perspectives in Sincu Bara, a first millennium site in the Senegal Valley. African Archaeological Review, 17(1), 1-41.

Melton, T., Peterson, R., Redd, A. J., Saha, N., Sofro, A. S., Martinson, J., \& Stoneking, M. (1995). Polynesian genetic affinities with Southeast Asian populations as identified by mtDNA analysis. The American Journal of Human Genetics, 57(2), 403-414.

Merriwether, D. A., Friedlaender, J. S., Mediavilla, J., Mgone, C., Gentz, F., \& Ferrell, R. E. (1999). Mitochondrial DNA variation is an indicator of Austronesian influence in Island Melanesia. American Journal of Physical Anthropology, 110(3), 243-270. doi:10.1002/(SICI)1096-8644 (199911)110:3<243::AID-AJPA1>3.0.CO;2-M.

Munson, P. (1971). The Tichitt Tradition: A late prehistoric occupation of the Southwestern Sahara. Ph.D. dissertation, University of Illinois at Urbana-Champaign.

Murdock, G. (1959). Africa: Its peoples and their culture history. New York: McGraw-Hill.

Murray, S., \& Deme, A. (in press). Early agro-pastoralism in the Middle Senegal Valley: The botanical remains from Walaldé. In D.Q. Fuller and M.A. Murray (Eds.) Flora, past cultures and archaeobotany in Africa. Walnut Creek: Left Coast Press.

Norris, H. T. (1986). The Arab conquest of the Western Sahara: Studies of the historical events, religious beliefs and social customs which made the remotest Sahara a part of the Arab world. Essex: Longman.

Oppenheimer, S. J., \& Richards, M. (2001). Polynesian origins. Slow boat to Melanesia? Nature, 410 (6825), 166-167. doi:10.1038/35065520.

Ottoni, C. (2008). Holocene human peopling of Libyan Sahara-Molecular analysis of maternal lineages in ancient and extant populations of Fezzan. Retrieved from https://irias.kuleuven.be/handle/123456789/ 240652

Paris, F. (1996). Les sépultures du Sahara nigérien du néolithique à l'islamisation; coutumes funéraires, chronologie, civilisations. Paris: IRD. 
Paris, F. (2000). African livestock remains from Saharan mortuary contexts. In R. M. Blench \& K. C. MacDonald (Eds.), The origins and development of African livestock (pp. 111-126). London: UCL Press.

Pawley, A. (2000). The chequered career of the Trans New Guinea phylum: Recent historical research and its implications. Papuan pasts: Investigations into the cultural, linguistic and biological history of the Papuan speaking peoples. Australian National University.

Pawley, A., \& Ross, M. (1993). Austronesian historical linguistics and culture history. Annual Review of Anthropology, 22, 425-459.

Petit-Maire, N. (1979). Le Sahara atlantique à l'Holocène. Peuplement et écologie. Alger: C.R.A.P.E.

Pierson, M. J., Martinez-Arias, R., Holland, B. R., Gemmell, N. J., Hurles, M. E., \& Penny, D. (2006). Deciphering past human population movements in Oceania: Provably optimal trees of $127 \mathrm{mtDNA}$ genomes. Molecular Biology and Evolution, 23(10), 1966-1975. doi:10.1093/molbev/ms1063.

Ponsich, M. (1967). Nécropoles phéniciennes de la région de Tanger. Tanger: Editions Marocaines.

Redd, A. J., \& Stoneking, M. (1999). Peopling of Sahul: mtDNA variation in aboriginal Australian and Papua New Guinean populations. The American Journal of Human Genetics, 65(3), 808-828. doi:10.1086/302533.

Redd, A. J., Takezaki, N., Sherry, S. T., McGarvey, S. T., Sofro, A. S., \& Stoneking, M. (1995). Evolutionary history of the COII/tRNALys intergenic 9 base pair deletion in human mitochondrial DNAs from the Pacific. Molecular Biology and Evolution, 12(4), 604-615.

Ribot, I. (2011). A study through skull morphology on the diversity of Holocene African populations in a historical perspective. Oxford: British Archaeological Reports.

Roberts, R., Jones, J. P., \& Smith, M. (1995). Beyond the radiocarbon barrier in Australian prehistory. Antiquity, 68, 611-616.

Robinson, D. (1971). Abdul Bokar Kan and the history of Futa Toro, 1853-1891. Ph.D. dissertation, Columbia University.

Robinson, D. (1975). Chiefs and clerics: Abdul Bokar Kan and Futa Toro, 1853-1891. Oxford: Clarendon Press.

Roncière, C. de la (1925). Découverte de L'Afrique au Moyen Age: Cartographes et explorateurs. La Société Royale De Géographie D'Egypte.

Rosa, A., \& Brehm, A. (2011). African human mtDNA phylogeography at-a-glance. Journal of Anthropological Sciences, 89, 1-34.

Rosa, A., Brehm, A., Kivisild, T., Metspalu, E., \& Villems, R. (2004). MtDNA Profile of West Africa Guineans: Towards a better understanding of the Senegambia Region. Annals of Human Genetics, 68 (4), 340-352.

Rosa, A., Ornelas, C., Jobling, M. A., Brehm, A. N., \& Villems, R. (2007). Y-chromosomal diversity in the population of Guinea-Bissau: A multiethnic perspective. BMC Evolutionary Biology, 7, 124-124.

Ross, M. (2005). Pronouns as a preliminary diagnostic for grouping Papuan languages. In A. Pawley, R. Attenborough, R. Hide, \& J. Golson (Eds.), Papuan pasts: Cultural, linguistic and biological histories of Papuan-speaking peoples. Pacific Linguistics: Canberra.

Ruiz-Pesini, E., Lott, M. T., Procaccio, V., Poole, J. C., Brandon, M. C., Mishmar, D., Wallace, D. C., et al. (2007). An enhanced MITOMAP with a global mtDNA mutational phylogeny. Nucleic Acids Research, 35 (Database issue), D823-D828. doi:10.1093/nar/gk1927.

Sadr, K. (1991). The development of nomadism in ancient Northeast Africa. Philadelphia: University of Pennsylvania Press.

Scheinfeldt, L., Friedlaender, F., Friedlaender, J., Latham, K., Koki, G., Karafet, T., Lorenz, J., et al. (2006). Unexpected NRY chromosome variation in Northern Island Melanesia. Molecular Biology and Evolution, 23(8), 1628-1641. doi:10.1093/molbev/ms1028.

Scheinfeldt, L. B., Soi, S., \& Tishkoff, S. A. (2010). Colloquium paper: Working toward a synthesis of archaeological, linguistic, and genetic data for inferring African population history. Proceedings of the National Academy of Sciences of the United States of America, 107(2), 8931-8938.

Schultz, E. A. (1984). From Pagan to Pullo: Ethnic identity change in Northern Cameroon. Africa: Journal of the International African Institute, 54(1), 46-64.

Scott, G. R., \& Turner, C.G. (1997). The anthropology of modern human teeth: Dental morphology and its variation in recent human populations. Cambridge: Cambridge University Press.

Scozzari, R., Torroni, A., Semino, O., Sirugo, G., Brega, A., \& Santachiara-Benerecetti, A. S. (1988). Genetic studies on the Senegal population. I. Mitochondrial DNA polymorphisms. The American Journal of Human Genetics, 43(4), 534-544. 
Semino, O., Santachiara-Benerecetti, A. S., Falaschi, F., Cavalli-Sforza, L. L., \& Underhill, P. A. (2002). Ethiopians and Khoisan share the deepest clades of the human Y-chromosome phylogeny. The American Journal of Human Genetics, 70(1), 265-268.

Simoons, F. J. (1971). The antiquity of dairying in Asia and Africa. Geographical Review, 61(3), $431-439$.

Smith, A. (1979). Biogeographical consideration of colonization of the lower Tilemsi Valley in the second millennium BC. Journal of Arid Environments, 2, 355-361.

Smith, A. (2005). African herders. Walnut Creek: Altamira Press.

Smith, A. C. (2012). Mobility and urbanism in Mali's Inland Niger Delta. Paper delivered at 21st Biennial Meetings of the Society of Africanist Archaeologists, June 21-23, Toronto, Canada.

Soares, P., Achilli, A., Semino, O., Davies, W., Macaulay, V., Bandelt, H.-J. R., Richards, M. B., et al. (2010). The archaeogenetics of Europe. Current Biology, 20(4), R174-R183.

Soares, P., Rito, T., Trejaut, J., Mormina, M., Hill, C., Tinkler-Hundal, E., Richards, M. B., et al. (2011). Ancient voyaging and Polynesian origins. The American Journal of Human Genetics, 88(2), 239-247. doi:10.1016/j.ajhg.2011.01.009.

Spedini, G., Destro-Bisol, G., Mondovì, S., Kaptué, L., Taglioli, L., \& Paoli, G. (1999). The peopling of sub-Saharan Africa: The case study of Cameroon. American Journal of Physical Anthropology, 110(2), 143-162.

Spriggs, M. (1997). The island Melanesians. Oxford: Blackwell.

Spriggs, M. (2011). Archaeology and the Austronesian expansion: Where are we now? Antiquity, 85, 510-528.

Stenning, D. J. (1959). Savannah nomads: A study of the Wodaabe Pastoral Fulani of Western Bornu Province Northern Region. Nigeria: LIT Verlag Münster.

Stoneking, M., Jorde, L. B., Bhatia, K., \& Wilson, A. C. (1990). Geographic variation in human mitochondrial DNA from Papua New Guinea. Genetics, 124(3), 717-733.

Summerhayes, G., \& Oxford University, P. (2007). Island Melanesian pasts: A view from archaeology. Genes, language, and culture history in the Southwest Pacific. Oxford: Oxford University Press.

Swift, J. (1979). The economics of production and exchange in West African pastoral societies. In M. Adamu \& A. H. M. Kirk-Greene (Eds.), Pastoralists of the West African Savanna. Manchester: Manchester University Press.

Tauxier, L. (1937). Moeurs et histoire des Peuls. Paris: Fayot.

Terrell, J. (1988). History as a family tree, history as an entangled bank: Constructing images and interpretations of prehistory in the South Pacific. Antiquity, 62, 642-657.

Thiaw, I. (1999). Archaeological investigations of long-term culture change in the lower Falemme (Upper Senegal Region): A.D. 500-1900. Ph.D. dissertation, Rice University, Houston, Texas.

Tishkoff, S. A., Reed, F. A., Friedlaender, F. R., Ehret, C., Ranciaro, A., Froment, A., Williams, S. M., et al. (2009). The genetic structure and history of Africans and African Americans. Science, 324(5930), 1035-1044.

Tishkoff, S. A., Reed, F. A., Ranciaro, A., Voight, B. F., Babbitt, C. C., Silverman, J. S., Deloukas, P., et al. (2007). Convergent adaptation of human lactase persistence in Africa and Europe. Nature Genetics, 39 (1), 31-40.

Underhill, P. A., \& Kivisild, T. (2007). Use of Y chromosome and mitochondrial DNA population structure in tracing human migrations. Annual Review of Genetics, 41, 539-564.

Underhill, P. A., Passarino, G., Lin, A. A., Shen, P., Mirazon Lahr, M., Foley, R. A., Cavalli-Sforza, L. L., et al. (2001). The phylogeography of Y chromosome binary haplotypes and the origins of modern human populations. Annals of Human Genetics, 65(Pt. 1), 43-62.

Underhill, P. A., Shen, P., Lin, A. A., Jin, L., Passarino, G., Yang, W. H., et al. (2000). Y chromosome sequence variation and the history of human populations. Nature Genetics, 26(3), 358-361.

van Oven, M., \& Kayser, M. (2009). Updated comprehensive phylogenetic tree of global human mitochondrial DNA variation. Human Mutation, 30(2), E386-E394.

Veeramah, K. R., Connell, B. A., Pour, N. A., Powell, A., Plaster, C. A., Zeitlyn, D., Thomas, M. G., et al. (2010). Little genetic differentiation as assessed by uniparental markers in the presence of substantial language variation in peoples of the Cross River region of Nigeria. BMC Evolutionary Biology, 10(1), 92-92.

Vernet, R. (1993). Préhistoire de la Mauritanie. Nouakchott: Sépia.

Vernet, R. (2001). Un habitat de l'Age du cuivre (2500 BP) de la région de Nouakchott (Mauritanie occidentale): Imbich-Est. Sahara, 12, 83-90.

Watson, E., Bauer, K., Rashid, A., Weiss, G., von Haessler, A., \& Pääbo, S. (1996). mtDNA sequence diversity in Africa. American Jurnal of Human Genetics, 59, 437-444.

Watson, E., Forster, P., Richards, M., \& Bandelt, H. J. (1997). Mitochondrial footprints of human expansions in Africa. The American Journal of Human Genetics, 61(3), 691-704. 
White, J., Allen, J., \& Specht, J. (1988). Peopling the Pacific: The Lapita Homeland Project. Australian Natural History, 22, 410-416.

Wollstein, A., Lao, O., Becker, C., Brauer, S., Trent, R. J., Nurnberg, P., Kayser, M., et al. (2010). Demographic history of Oceania inferred from genome-wide data. [Research Support, Non-U.S. Gov't]. Current Biology, 20(22), 1983-1992. doi:10.1016/j.cub.2010.10.040.

Wurm, S. A. (1967). Linguistics and the prehistory of the South-Western Pacific. The Journal of Pacific History, 2, 25-38.

Wylie, A. (2002). Rethinking unity as a "working hypothesis" for philosophy of science. Thinking from things: Essays in the philosophy of archaeology (pp. 200-210). Berkeley: University of California Press. 